\title{
Innovative management accounting practices for sustainability of manufacturing small and medium enterprises
}

\author{
S. N. Nartey ${ }^{1} \cdot$ H. M. van der Poll ${ }^{2}$ (D)
}

Received: 21 May 2020 / Accepted: 10 April 2021 / Published online: 23 April 2021

(c) The Author(s) 2021

\begin{abstract}
The environment in which manufacturing small and medium enterprises operate has become very complex, and therefore manufacturing SME's owners need to be aware of the impact their decisions have on the environment and society. The aim of the research was to identify which innovative management accounting practices can be integrated into manufacturing SMEs' strategies to overcome the challenge of being blamed by stakeholders as contributors to social and environmental problems. Published articles were sourced from the University of South Africa's online library using keywords. A systematic literature review was employed to discover themes and concepts during secondary data gathering to detect traditional and innovative MAPs in management accounting literature all over the globe. The qualitative data analysis and research software, Atlas.ti was used to synthesise the data. Thematic analysis was used to evaluate the occurrence of words, phrases, themes, metaphors, and the construction of concepts in MAPs literature. During the analysis, seven innovative MAPs (activity base costing/budgeting; product life cycle costing; total quality management; environmental costing; target costing; kaizen costing and value analysis) were identified. It is recommended that manufacturing SMEs integrate these innovative MAPs into their strategies to impact their environmental, social, supply chain management and recycling policies to promote operational efficiency to achieve sustainability. Further research to identify influencing factors; strategic procedures; and the environmental and social benefits of integrating these identified innovative MAPs into manufacturing SMEs to achieve sustainability, should be undertaken.
\end{abstract}

Keywords Environment - Innovative management accounting practices · Manufacturing · Small and medium enterprises $\cdot$ Social $\cdot$ Sustainability

H. M. van der Poll

vdpolhm@unisa.ac.za

S. N. Nartey

nsanarh@gmail.com

1 Department of Management Accounting, Unisa, Pretoria, South Africa

2 Graduate School of Business Leadership, Unisa, Midrand, South Africa 


\section{Introduction}

Manufacturing controls the well-being and wealth of every economy; however, it also directly or indirectly leads to the depletion of the ecosystem and burdens society (Bonvoisin et al., 2017). As a result, society today blames manufacturing enterprises as partly causing global social and environmental problems (Capros et al., 2016). Therefore, high profile multi-national enterprises are also experiencing pressure from stakeholders and broader society to contribute towards environmental sustainability (Syakir et al., 2017; Wangombe, 2013). Jalaludin et al. (2011); Lucas et al. (2013) and Ntalamia (2017) argue that for enterprises to mitigate this pressure from stakeholders, they may need to integrate Management Accounting (MA) into their strategy to help reduce the pressure tarnishing their image in society. Nair and Nian (2017); and the Chartered Institute of Management Accountants (CIMA, 2014), describe MA as the process to assist with decision-making to create value and guarantee sustainable achievements. This is attained when the information provided and analysed allows enterprises to plan, implement and control their strategies. Furthermore, MA provides managers with information to make sound decisions (Dubihlela \& Rundora, 2014; Matambele \& van der Poll, 2017; Ratnatunga et al., 2015; Tilt, 2018). As a result, the number of enterprises that integrates MA as a practice to disclose their impacts through social and environmental activities in annual reports has increased substantially during the past few years (CIMA, 2014).

However, research shows that manufacturing Small and Medium Enterprises (SMEs) are mostly unwilling to integrate environmental strategies or accept voluntary strategies such as ISO14001 and ISO14004 (Mat et al., 2018; Tuczek et al., 2018). Despite the increased number of studies on MAPs over the decades, little is known about innovative MAPs' integration effectiveness into SMEs' strategies (Ahmad, 2017; López \& Hiebl, 2015; Shields \& Shelleman, 2015). Furthermore, Volker (2015); and Nair and Nian (2017) argue that large enterprises are favoured for MA empirical research since they have the expertise and capacity that promotes innovative MAPs' integration. This may create challenges for the study of innovative MAPs in manufacturing SMEs. However, Lynch-Wood and Williamson (2014); and Volker (2015) argue that studies into SMEs may provide different data and settings on fundamental explanations and understanding of the practices within the SMEs sector. They argue that SMEs might even provide less complex settings, which is not provided by large enterprises.

According to the researchers, the literature review shows that little research was undertaken in an attempt to identify suitable innovative MAPs for manufacturing SMEs' sustainability. Alkhajeh and Khalid (2018) argue that MAPs have an impact on SMEs performance that may lead to increased productivity. According to Maziriri and Mapuranga (2017); and Kefasi (2019), manufacturing SMEs in the Gauteng and Western Cape provinces, which are industrial hubs in South Africa, uses traditional MAPs in costing, budgeting, performance evaluation, decision-making and strategic analysis. Furthermore, Ngibe and Bingwa (2020) identified that even though manufacturing SMEs' managers are clearly aware of the strategic impacts and benefits of integrating contemporary MAPs as an innovative strategy for sustainability, due to economic challenges associated with its integration, they opt for traditional MAPs. Bearing this in mind, the researchers sought to address the problem by identifying innovative MAPs that can assist manufacturing SMEs to achieve environmental and social sustainability. As a result, the following research question will be addressed:

Which innovative MAPs can be integrated into manufacturing SMEs' strategy to achieve environmental and social sustainability? 
To answer the research question above, the under listed sub-questions were dealt with:

RSQ1: What are the traditional and innovative MAPs that manufacturing SMEs can integrate into their strategy?

RSQ2: Which innovative MAPs have environmental, social and sustainable development impacts on manufacturing SMEs' decision-making?

The main finding concludes that innovative MAPs can enable manufacturing SMEs to protect the environment and society through integrating sound environmental; health and safety; supply chain management and recycling polices that may enhance their operational efficiency and subsequently promote their achievement of economic sustainability in the long run. The research breaches the existing gap between theory and practice by identifying seven (7) innovative MAPs that manufacturing SMEs can integrate into their strategies to achieve sustainability.

The structure of this article is as follows: the background to the study is portrayed by defining SMEs and their role in the economy, discussing management accounting practices (MAPs), management accounting change and environmental and social changes in MAPs. This is followed by the research methodology, data analysis and a discussion on the findings. Finally, the article concludes highlighting the findings, contributions, limitations and further research suggestions.

\section{Background}

\subsection{Definition and the role of SME's in the economy}

SMEs have no singular definition universally and are therefore, defined differently by various countries' legislative frameworks. In South Africa, they are known as small and medium enterprises (SMEs) or small businesses. The National Small Enterprise Act (Act 2019) in South Africa defines an SME as a "separate and distinct business entity, together with its branches or subsidiaries, if any, including cooperative enterprises, managed by one owner or more, predominantly carried on in any sector or subsector of the economy" (Act 2019:1). They employ less than 250 employees and have a turnover of less than R170 million. Although Australia has a number of SMEs and acknowledges their contribution to the economy, they do not have a uniform legislative definition (Commonwealth of Australia, 2018). However, they do indicate that if it is a manufacturing enterprise, the enterprise employs less than 100 employees. The European Commission (2015) defines an SME as an enterprise employing less than 250 employees, annual turnover less than Eur 50 million or a balance sheet total less than Eur 43 million. They also value SMEs as engines of growth. The US small Business Administration (SBA, 2013) introduces Small and Medium Sized Manufacturers in the United States of America (USA) as those enterprises employing less than 500 employees and having less than $\$ 100$ million sales.

The development of SMEs is the first step towards economic development and industrialisation (Mat et al., 2018) and they are therefore an engine of growth through which economic objectives are achieved (Ayub, 2018; Dubihlela \& Rundora, 2014: 28; Mat et al., 2018). SMEs contribute to a healthy economic sector through creating employment opportunities; high production units; export growth; and the introduction of innovation and entrepreneurial skills (Mahembe et al., 2011: 14; Le et al., 2018). Therefore, governments 
all over the globe are initiating strategies to safeguard the development of a vibrant SME sector to promote their sustainability (Olalekan \& Jumoke, 2017). Hence, SMEs have come under the spotlight among management accountants and scholars all over the globe (Ayub, 2018; Johnson \& Schaltegger, 2016).

\subsection{Management accounting practices (MAPs)}

Technological advancement is causing complex change across the globe hence; enterprises are susceptible to change (CIMA, 2014: 1; Neziraj \& Shaqiri, 2018: 22). Currently, large enterprises and SMEs are competing to be the most innovative in the twenty-first century. The idea of long-standing economic improvement is being challenged as both the capacity and speed of data delivery escalate (CIMA, 2014: 2; Neziraj \& Shaqiri, 2018: 22). Most importantly, enterprises are doing more to react correctly to emerging risks and defend their created economic values when information is not abundant, difficult or demand complex technology to interpret (CIMA, 2014: 6; Matsoso \& Benedict, 2014: 248; Neziraj \& Shaqiri, 2018). Against this backdrop, MA is more relevant than ever and in general, is defined as a system that identifies, measures, evaluates, accumulates, analyses, prepares, and interprets data to assist management in decision-making to achieve the enterprise's objectives (Ahmad \& Leftesi, 2014; Radović-Marković \& Vučeković, 2015: 186; Drury, 2018). Drury (2018) argues that MAPs deal with the provision of information to improve the enterprise's internal decision-making, performance and efficacy in the enterprise's strategy. MAPs enable forward-looking internally and creates structured answers to unstructured problems, enables enterprises to gather information that ensure strategic decisions are reached and reported meritoriously (CIMA, 2014: 3; Neziraj \& Shaqiri, 2018). Therefore, MAPs may be suitable to be integrated into manufacturing SMEs strategies to facilitate effective decision-making towards sustainability.

The need for MAPs to be integrated is that, MAPs create sustainable values through sound decision-making by ensuring complete analysis of data to support SMEs to evaluate, plan, coordinate, and control the implementation of their strategies (CIMA, 2014: 5). Furthermore, MAPs facilitate the accessibility of appropriate and correct information to back enterprise's activities for effective decision-making. Hence, SMEs' sustainability and long-term value will be created for stakeholders (CIMA, 2014: 6; Neziraj \& Shaqiri, 2018). Rufino (2014) argues that the adoption of innovative MAPs by enterprises to counter environmental and social changes was stimulated by the global crises facing enterprises. MAPs are business practices, which may assist enterprises to create value with sustainable development through the technical skills of management accountants (Nuhu et al., 2016). Through training, management accountants develop special knowledge to uniquely place them to contribute to enterprises' sustainability (Prowle \& Lucas, 2016). Innovative MAPs produce evidence-based reports to solve management problems such as costing, risk and value analyses in enterprises' strategy and provide data justification (CIMA, 2014; Sharma, 2015). Amara and Benelifa (2017) argue that innovative MAPs harmonised the internal and external factors of enterprises. Furthermore, it also assists management accountants to collect, evaluate and analyse available data and develop scenarios to project alternative outcomes that may benefit the enterprise's objectives in the context of social and environmental factors (Namazi, 2013). This data flow is shown in Fig. 1.

Figure 1 supports Rufino's (2014); and Matambele and van der Poll's, (2017) argument that MAPs are accounting practices that support management decision-making 


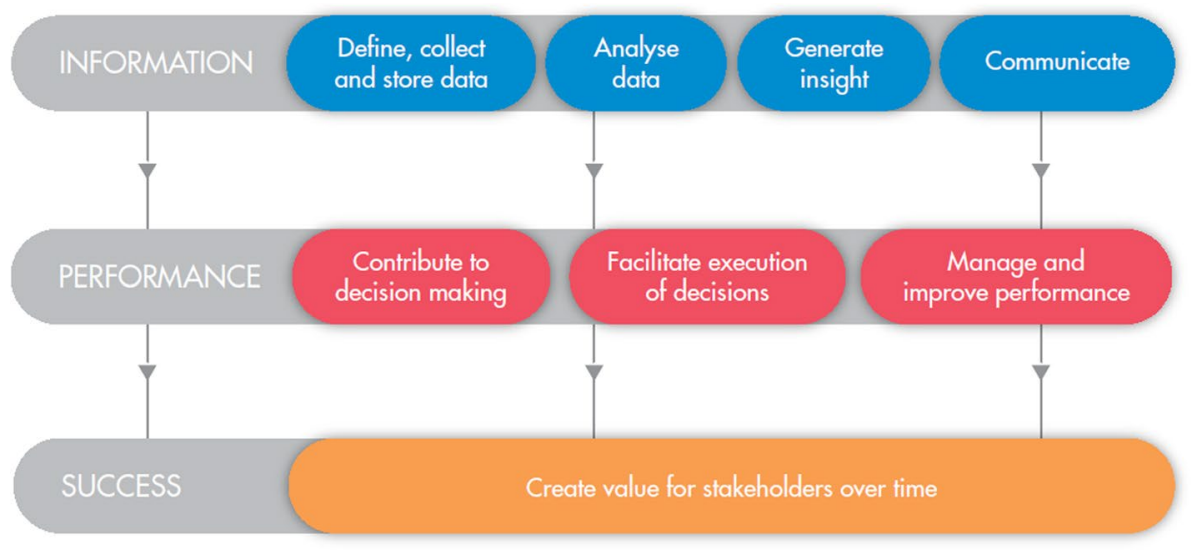

Fig. 1 Management accounting information flows. Source: CIMA (2014:6)

internally based on economic, monetary and non-monetary data generation. Hence, MAPs assist decision-making which might promote manufacturing SMEs sustainability.

\subsection{Management accounting change}

The most important challenge confronting enterprises in this technology age is the process of acquiring the right mix of data to plan cost of production, quality and timerelated activities in enterprises (Matsoso \& Benedict, 2014). According to Shah et al. (2011), traditional MAPs identified in RSQ1 (Fig. 3) is inadequate to provide the necessary information in this twenty-first century. They argue that traditional MAPs focuses on the past, are too narrow and mislead managers to plan, evaluate and control decisionmaking of enterprises in the emerging era when planning, evaluating and controlling. The reason being that these MAPs focus on expired information (reports on transactions that have already taken place and not what is expected). Moreover, Ramljak and Rogošić (2012) argue that the emphasis of traditional MAPs also neglects the environmental issues where management decisions are taken and integrated into an enterprise's strategy as a major weakness in the 21 st-century business contextualisation. According to Amara and Benelifa (2017), many factors influence the change in MA within enterprises. They argue that environmental uncertainty, structures, size, activities, market competition, technology, design, information complexity and strategies are drivers of change in enterprises. According to Ntalamia (2017), such changes may originate owing to diverse factors in the economic and cultural environment. As a result, some studies focus on changes in MAPs (Alleyne \& Weekes-Marshall, 2011; Tuanmat \& Smith, 2011; Sunarni, 2013:616). Furthermore, IoDSA (2016:14) argues in the King IV report that the economic business environment has changed with the advent of fast-moving technology's influence on the strategic activities of enterprises. Hence, manufacturing SMEs may need to change from traditional MAPs to innovative MAPs that may provide them with the necessary tools to compete effectively in the twenty-first century.

The next section discusses the environmental and social MAPs changes. 


\subsection{Environmental and social changes in management accounting practices}

Global competition may be leading all enterprises towards reformed obligations, high levels of operational excellence and competitiveness (Dubihlela \& Rundora, 2014:27; Smith, 2015:76; Hamann et al., 2017). With economic instability, Annandale (2013:54) and Hamann et al. (2017) enquired how SMEs can benefit from sustainability. To answer this, it is argued in this article that by integrating innovative MAPs into SMEs' strategy, management would be able to identify environmental, social, and economic strengths, weakness, opportunities and threats (SWOT) during decision-making. Innovative MAPs as seen in enterprises in the twenty-first century involve environmental and social changes, emanating from enterprises' change prompted by a new interest in practices relating to sustainability. This rise of innovative MAPs attracted the attention of various scholars (Ahmad, 2017; Ahmad \& Zabri, 2016; Azudin \& Mansor, 2017; Bonvoisin et al., 2017; Maziriri \& Mapuranga, 2017; Nair \& Nian, 2017; Nuhu et al., 2016; Prowle \& Lucas, 2016). These scholars have mainly been evaluating which MAPs such as costing, budgeting, planning, pricing and performance strategies in enterprises have changed to embrace environmental and social issues (Cuzdriorean, 2017; Nair \& Nian, 2017; Rufino, 2014; Uyar, 2010). Their studies identify the changes to comprise environmental strategies, health and safety strategies, legal regulations, inclusive total quality management (TQM), and sustainable development. Furthermore, the scholars argue that environmental strategic prospects are identified in the process of integrating, that is, environmental technology, energy conservation strategy, products design, market packaging, and recycling. These activities demand innovative MAPs to evaluate strategic cost/benefits analysis, alternative cost savings scenario's, full life-cycle costing (LCC), activity-based costing (ABC), reports on waste control, investment appraisals, management control and performance evaluation (Biernacki, 2015; Ntalamia, 2017; Nucci et al., 2016; Testa et al., 2011). For instance, innovative MAPs might identify, measures and link environmental and social accounts to capital budgeting (Ndwiga \& van der Poll, 2013; Nuhu et al., 2016). Therefore, innovative MAPs may be viewed as those practices that support internal management to perform their function of planning, controlling, decision-making, evaluation, and long-term strategic development.

According to Biernacki (2015), innovative MAPs are not necessarily seeking the abolishment of traditional MAPs, however, it is more of the integration of environmental and social practices into MA. Hence, Namakonzi and Inanga (2014); and Maziriri and Mapuranga (2017:20) argue that innovative MAPs are holistic concepts, which combine environmental and social activities and integrates them into enterprises' strategy to assist environmental and social costs' identification and the measurement of production efficiency. These main functions relate to human, social, economic, and environmental aspects which manufacturing SMEs should report (Arena \& Azzane, 2012; Lemus, 2016).

From an environmental viewpoint, SMEs are known to be irresponsible, owing to their limited knowledge of MAPs (Ramli \& Ismail, 2013; Mat et al., 2018, Ngibe \& Bingwa, 2020). As a result, there may be a need for regulatory agencies to be careful when designing frameworks and regulations to ensure that such policies promote benefits for SMEs' involvement in environmental and social sustainability (Jamil et al., 2015; Nair \& Nian, 2017:182). According to Vandayar (2015:54) and Smith (2015), corporate governance philosophies are not only responsible for the survival of large enterprises; SMEs can also benefit from integrating such strategies that reinforce professional behaviour. Stubblefield et al. (2010) argue that the major reason for SMEs to adopt innovative MAPs is not the leading edge, however, it is since the 
planet matters to them. As MAPs change to accommodate social and environmental impacts of enterprises in management accounting, manufacturing SMEs may stand a chance to effectively protect the environment, which supports their existence to achieve sustainability through the integration of innovative MAPs.

\section{Research methodology}

The method employed in this research involved a systematic literature review. This is considered appropriate in order to address the research problem. Marshall and Rossman (2014) advocate that the researcher should firstly consider data analysis issues pertaining to the research and secondly, processes of analysing conceptual qualitative data begins at the moment data is collected and proceeds thereafter (Creswell, 2014). Hence, the researchers considered the research questions and decided to conduct a systematic literature review. The researchers opted to use desktop research as a tool to collect the necessary literature to answer the questions. The Unisa Library was used to search for all the necessary frameworks, publications, and articles on MAPs, SMEs and theoretical frameworks globally.

\subsection{Data collection process}

During this data collection process 350 articles were identified using the following keywords:

- Innovative management accounting practices;

- Management accounting;

- Management accounting change;

- Environmental and social accounting change;

- Sustainability accounting;

- Sustainability management accounting;

- Innovative management technology;

- Environmental management accounting;

- Environmental management system; and

- Social accounting.

The researchers deemed it appropriate to adopt the philosophy of Creswell (2014), and Wouters et al. (2016) to track subject concepts and data from a wide range of literature through which the following articles were rejected:

- Articles that only mentioned MAPs briefly, however, the content was misaligned with the scope of this research.

- Articles that mentioned MAPs, however, it was articles referred to in the reference list.

- Articles where MAPs were not mentioned at all (that is, the article pops up due to a search term as a result of words in phraseology or at the end, or due to another language -connected context or the abbreviation of the MAPs however a different connotation).

- Articles which are antecedent of alternative articles with less data important to the research. 
- Articles that were an introduction to another article or merely constituted a brief systematic literature review or an abstract of successive articles.

The screening identified 60 articles suitable for analyses. The conceptual data collection process requires an interactive stable movement of concepts and data, and related continuous procedures across all indications to regulate the level and scope evolved in data (Creswell, 2014). The following data collection processes were adopted:

- Mapping of data routes;

- Analysing and classifying the identified data;

- Recognising and coding of concepts;

- Deconstructing and sorting of concepts;

- Integrating and re-integrating concepts;

- Synthesising, and re-synthesising to make sense out of them all;

- Establishing credibility, transferability and conformability of concepts; and

- Re-thinking of the concepts and frameworks.

\subsection{Data analysis}

A thematic analysis was used in this qualitative study. This choice was justified by the arguments of the under-mentioned scholars. Bryman and Bell (2015) define thematic analysis as a method that analyses documents and scripts to enumerate content relating to prearranged groupings, methodical and in a replicable manner. The major practice of thematic analyses comprises coding the collected data in order to identify a qualitative data set for analyses (Cooper \& Schindler, 2014). Furthermore, Saunders et al. (2016) propose three (3) main sources to derive names for coding:

- Using terms that appear in data;

- Actual terms used by study participants; and

- Terms used in existing literature.

The thematic data were derived from existing literature. The researchers considered it a suitable approach to use a thematic analysis to understand the meaning and the content of the MAPs literature. The qualitative data coding and analyses software of Atlas.ti was used to synthesise data from the identified MAPs literature.

\subsection{Trustworthiness of the study}

Bashir et al. (2008:38) argue that a paradigm is a worldview that bridge ontology, epistemology, axiology and the quality of a social study completed within a paradigm must be judged by its own paradigm's terms. Centred on the perception of various constructed realities, it is more vital for qualitative research to demonstrate that its findings are credible, transferable and conformable as follows:

- Credibility To certify the credibility, the researchers ensured that the literature used in the research were predominantly from peer-reviewed published articles.

- Transferability To ensure transferability, the researcher compared MAPs literature from different settings and continents. 
- Confirmability An audit trail was left when the researchers discussed the details of the process of data collection, data analysis, and interpretation of the data.

- Dependability Other researchers have enough information to replicate the research and obtain similar findings.

\section{Data analysis}

Innovative MAPs provide management with information for internal solutions. The problem is how to identify specific innovative MAPs that manufacturing SMEs can integrate into their strategies to achieve sustainability. In this research, the researchers employed figures and tables to make conclusions meaningful to communicate and answer the main research question:

Which innovative MAPs can be integrated into manufacturing SMEs' strategy to achieve environmental and social sustainability?

To answer the main research question, the research sub-questions (RSQ) were answered next.

RSQ1: What are the traditional and innovative MAPs that manufacturing SMEs can integrate into their strategy?

To answer RSQ1, the data analysis identified traditional and innovative MAPs generally employed by manufacturing SMEs as depicted in Fig. 2.

The researchers have been able to identify MAPs from synthesised and reviewed articles and have categorised them into traditional and innovative MAPs as shown in Fig. 2 to simplify understanding.

RSQ2: OWhich innovative MAPs have environmental, social and sustainable development impacts on manufacturing SMEs' decision-making?

To answer RSQ2, the data analyses revealed that for manufacturing SMEs to cope with changes in time and modern technology, strategies have to be integrated with MAPs that provide management with all-round information to deal with enterprises' environmental and social impacts (Ghorbel, 2016), since innovative MAPs relate to providing solutions to management internally (Nuhu et al., 2016). Managing environmental impacts of enterprises involves the control of environmental and social effects of enterprises' actions and their effects on the ecosystem (ISO14004, 2016; Bebbington \& Unerman, 2018). Ntalamia (2017:6) argues that to avoid manufacturing SMEs incurring high environmental and social costs, they may need to integrate innovative MAPs to reduce such costs. Though many innovative MAPs were identified in Fig. 3, the study considers innovative MAPs that may promote manufacturing SMEs' sustainability as MAPs which may impact the decisionmaking of SMEs regarding the environment, society and sustainable development. Hence, the innovative MAPs for sustainability are MAPs that can impact decision-making on the three (3) footprints of manufacturing SMEs' strategies as presented in Fig. 3. 


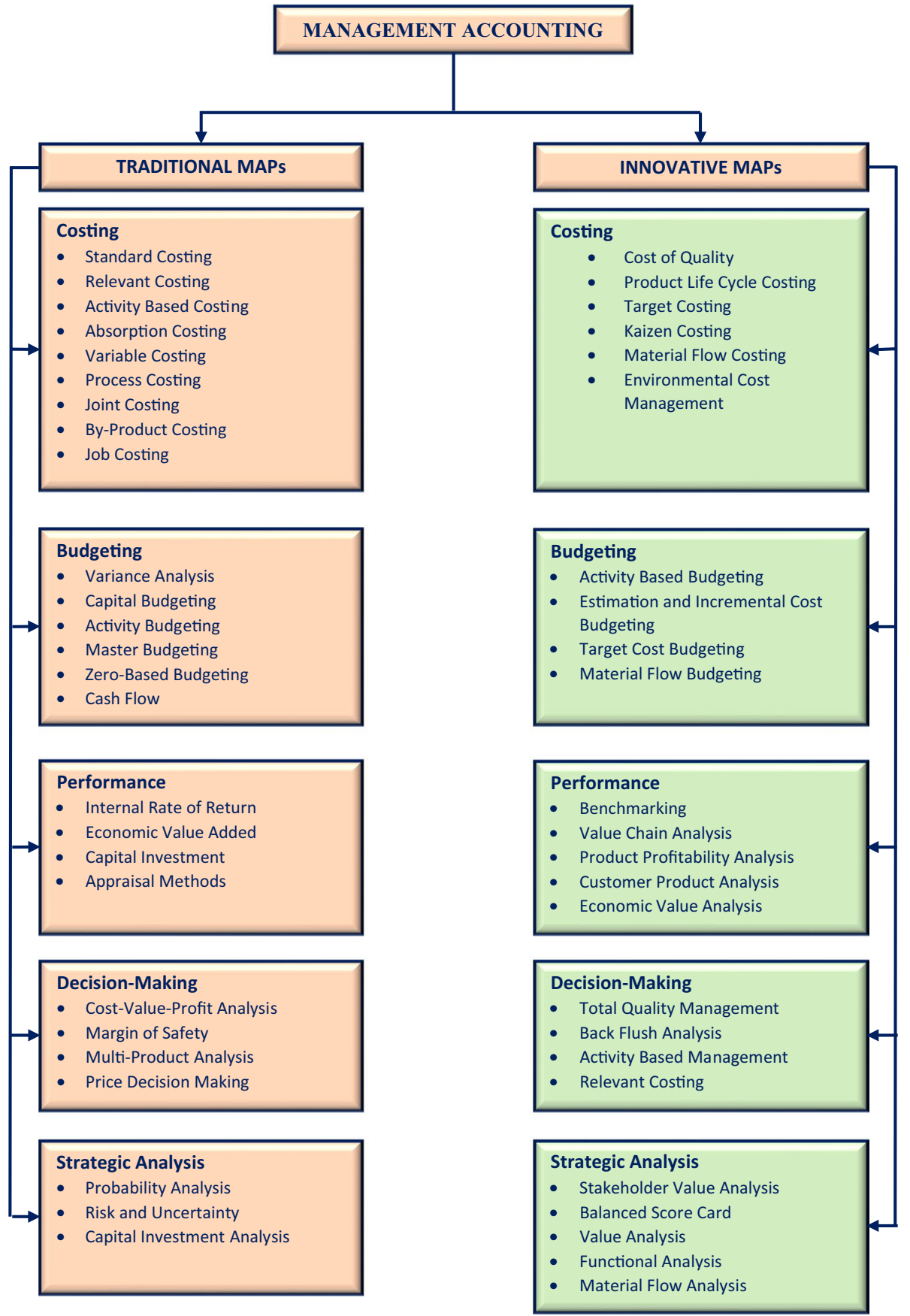

Fig. 2 Traditional and innovative MAPs (Authors' own) 


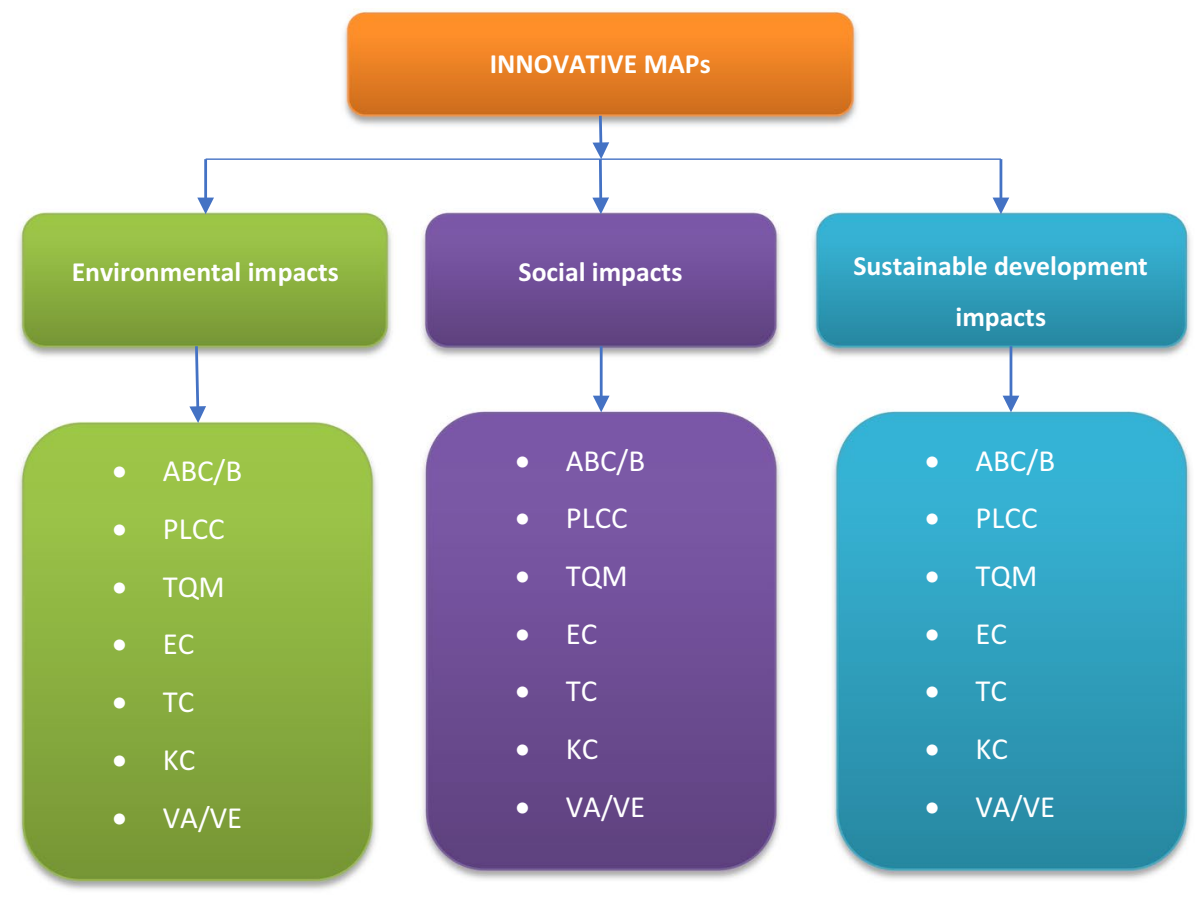

Fig. 3 Sustainability MAPs (Authors' own)

In Fig. 3 the data analysis has identified seven (7) innovative MAPs which cut across all three (3) footprints, namely:

- Activity base costing/budgeting (ABC/B)

- Product lifecycle costing (PLCC)

- Total quality management (TQM)

- Environmental costing (EC)

- Target costing (TC)

- Kaizen costing (KC)

- Value analysis (VA)

These seven (7) innovative MAPs will be discussed in the findings section.

\section{Findings}

To conclude this research, the innovative MAPs identified from the data analyses which may assist manufacturing SMEs to protect the environment and society when integrated into their strategies to achieve sustainability are therefore discussed next. 


\subsection{Activity-based costing/budgeting (ABC/B)}

$\mathrm{ABC} / \mathrm{B}$ focuses on managing the variety of activities that SMEs engage in. It is structured on the principles that activities consume costs. Consequently, by controlling activities, costs are controlled in the long-term (Dubihlela \& Rundora, 2014; Mahal \& Hossain, 2015). ABC/B aims to facilitate client approval whilst making a few changes to SMEs' resources. Ascertaining activity costs permit activities with a high cost to be identified and prioritised for a thorough study to determine if they can be performed more efficiently or eliminated (Drury, 2018; Tsai et al., 2010). The integration of ABC/B into manufacturing SMEs' strategy will allow management to:

- Identify major activities in the SME;

- Assign costs to each activity;

- Identify cost drivers for every main activity; and

- Allocate cost to each activity in accordance with the product's demand.

$\mathrm{ABC} / \mathrm{B}$ may offer appropriate target areas to reduce environmental and social costs in product designing. Hence, manufacturing SMEs may allocate costs to processes and further activities using environmental data provided by $\mathrm{ABC} / \mathrm{B}$ methods for decision-making on sustainability (Andersson et al., 2011). As a result, management might become efficient in identifying the real production costs and offer insights for improving on-going processes in manufacturing SMEs. Hence, $\mathrm{ABC} / \mathrm{B}$ was identified as an innovative MAP that may assist SMEs to be sustainable.

\subsection{Product life cycle costing (PLCC)}

According to Biernacki (2015); Nucci et al. (2016) and Drury (2018) PLCC projects and calculates a product's cost cumulatively over its total life cycle to ascertain if the expected profit in the manufacturing stage will defray the costs incurred over the entire manufacturing stage. They furthermore maintain that the identified costs incurred over several stages of a product's life cycle may offer an understanding of the product's total costs accumulated in its life cycle. Accordingly, PLCC gives management an understanding of the magnitude of a cost structure by detecting areas in which a reduction strategy can be affected. Testa et al. (2011) argued that PLCC certifies that enterprises decision-making is centred on increasing awareness of the perspective problem in terms of costs on the environment and society at the product design phase. Furthermore, Arena and Azonne (2012) indicated that PLCC can facilitate sustainability through the integration of innovative MAPs such as TC, VA, PLCC and ABC which are powerful management tools that SMEs can use

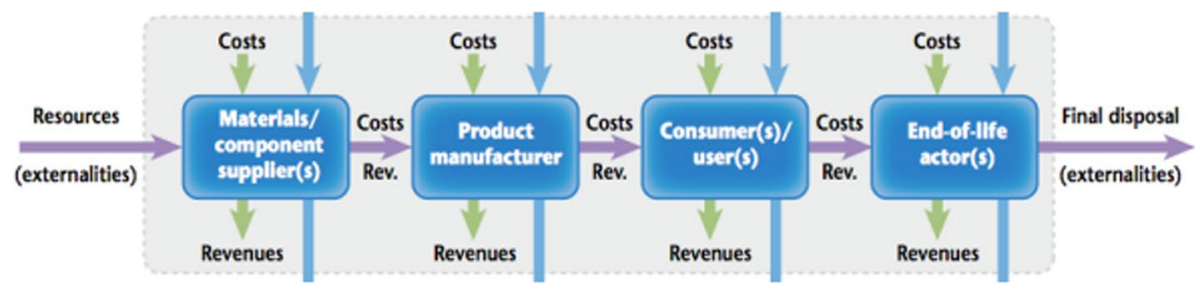

Fig. 4 Product life cycle cost and revenue tracking. Source: Rebitzer and Hunkeler (2003) 
to overcome the challenges faced in implementing general sustainability standards. PLCC includes allocating costs and revenues on a product-by-product basis over various phases throughout the life cycle as depicted in Fig. 4.

Figure 4, shows that management can use PLCC as a practice to identify cost components in products which may impact negatively on the environment and society to be eliminated in subsequent product design stages before the cost is committed into production. Hence, the identification of PLCC as innovative MAPs for manufacturing SMEs sustainability.

\subsection{Total quality management (TQM)}

TQM is a method that permits manufacturing SMEs to estimate the degree to which its resources are employed in activities that prevent poor quality. These costs are grouped into three (3) categories: preventive, appraisal and failure cost. Its purpose is to attract management attention to prioritise quality standards (Barone, 2020). Drury (2018) argues that TQM is a tool that may assist management to compete effectively in the twenty-first century by making clients' satisfaction an overriding priority. TQM is a practice used by management accountants in the setup of an SME. It assists internal management to meet clients' demands and improves service levels regarding costs, quality, dependability, supply and high-quality in innovation.

It is plausible that the integration of TQM as an innovative MAP into manufacturing SMEs' strategies may assist managers to achieve quality goals through the provision of the under-listed reports as per Drury (2018):

- Preventive costs Assist to report on costs of prevention, maintenance, and quality planning, training and the additional cost of obtaining advanced quality materials. This will draw management's attention to devise strategies at the product design stage to reduce or eliminate such costs.

- Appraisal costs Assist to report on costs of checking materials, inventory-in-progress and completed inventory, audits and fields trials.

- Internal failure costs Assist to present an internal assessment report on materials or products that fail to meet quality standards. Hence, management will be able to establish costs that will be incurred on products' ratification before they are dispatched to clients such as re-work, cost of scraps, downtime and stoppages caused by defects.

- External failure costs Managers will be able to assess costs that will be incurred on products and materials dispatched to clients that have failed to meet quality standards. These costs may involve the cost of controlling a client's grievances, guarantee replacement, repairs of returns and cost of impaired enterprise image.

When these costs, which are components of TQM, are integrated into SMEs' strategies, it may generate reports that will support management to identify and control the above costs internally (Boca, 2011). TQM will provide management with information to determine the potential savings to be gained by implementing process improvement (Mohamad \& Wahab, 2017; Sahoo \& Yadav, 2018). This confirms the Sigma philosophy, which strives to achieve zero defects in the production process the first time rather than to rectify (Cuzdriorean, 2017). Hence, management will devise strategies to minimise these costs to the best possible level or eliminate them entirely during products' design stages to increase manufacturing SMEs' sustainability. 


\subsection{Environmental costing (EC)}

Environmental costing (EC) is a method of determining costs linked to the real or prospective depletion of natural assets owing to economic undertakings of an enterprise. EC ensures that SMEs' resources, processes, obligation, planning activities and structures are developed to implement, attain, appraise, and maintain environmental strategies. The data analyses uncovered that SMEs have challenges to integrate the right innovative MAPs into their strategy to assist them to track environmental costs to facilitate decision-making (Ntalamia, 2017). Moreover, Drury (2018) argues that environmental costs are accrued in different cost pools, analysed into suitable classifications and traced to the products that caused the cost with the help of ABC no matter the size of the SME. Such knowledge may assist management accountants to categorise environmental costs and their causes. It may also provide management with information needed to manage such costs effectively through process designs to reduce pollutants emitted into the environment. Manufacturing SMEs with their scarce resources might integrate EC into their strategies to assist them identify and manage environmental costs through the following techniques (Drury, 2018):

- Environmental prevention cost It is a strategic tool used to avert waste that may cause or impair the environment at the product design stages. This may comprise costs connected to product design and operational routes to minimise pollutants, products recycling and gain accreditation relating to national and international environmental standards.

- Environmental detection cost It is used to trace products, activities and procedures that do not adapt to controlling laws and standards at the product's design stages. This may assist managers to inspect manufacturing products and procedures to ensure environmental compliance, audits and tests.

- Environmental internal failure costs It is a practice used to identify costs incurred from executing activities that may produce containments and waste discharges into the environment. These are costs incurred by rectifying or minimising waste which do not comply with controlling laws and are brought to management's attention for decisionmaking during the product design stages.

- Environmental external failure costs It is a cost incurred on the activities after discharge of waste into the environment. These are costs of renovating contaminated soil, land restoration, oil spills, and waste discharged clean-up costs that are brought to management's attention for decision-making during the product's design. Management could, therefore, establish measures at the manufacturing design stage to reduce or eliminate such a cost entirely.

With the integration of EC into manufacturing SMEs' strategies, society may be assured that negative environmental impacts of SMEs could be minimised or eliminated entirely in the manufacturing SMEs' sector.

\subsection{Target costing (TC)}

Target costing is a practice that assists enterprises' management to estimate a target price, production costs and the expected margins for a new product (Hendricks, 2015). Where such manufacturing projections cannot be achieved, management may cancel the designing of the product entirely (Romanova et al., 2017; Volker, 2015). According to Drury (2018), the prime 
aim of TC is to support management to employ practical cost planning and management by integrating cost reduction strategies during the product design and development cycle.

The principles of TC are:

- Price led costing;

- Cross purpose teams;

- Client emphasis;

- Emphasis on products design;

- Life cycle cost minimisation; and

- Value chain investment appraisal.

The integration of TC into manufacturing SMEs' strategy may ensure inclusive cost planning, management and control principles are integrated at the primary stages of product design in order to impact cost structures for sustainability.

\subsection{Kaizen costing (KC)}

Kaizen costing $(\mathrm{KC})$ is a method that can be integrated into the manufacturing stage of PLCC (Drury, 2018). The purpose of KC in MA is to achieve cost reduction primarily through increased efficiency in production. The possible cost reduction takes place, one slight pace at a time, to solve precise problems since these products are already in the manufacturing phases of the life cycle. Hence, a significant amount of cost has been locked in.

The real power of $\mathrm{KC}$ is to create a small amount of perfection repeatedly in the processes or reduce waste (Romanova et al., 2017). As a result, KC depends on employee empowerment as they are presumed to have more infomration on the product and the best way out to increase its efficiency in the production line (Romanova et al., 2017). The philosophy of $\mathrm{KC}$ creates a culture that places more importance on the working environment as an actual place of improvement and a source of evidence concerning the improvement of the enterprises (Mind Tools, 2018).

According to Boca (2011), when enterprise management is thinking of going green, $\mathrm{KC}$ is one of the innovative MAPs that can be employed to promote enterprises' environmental friendliness. Hence, manufacturing SMEs may stand a chance of achieving environmental and social sustainability when integrating it into their strategy.

\subsection{Value analysis (VA)}

Value analysis is a method that applies a systematic, inter-disciplinary valuation of causes that affect production costs in order to devise appropriate ways of realising the exact activity most economically at the prerequisite quality (Ismail et al., 2010). The benefit of VA aims at a specific product or process to increase efficiency in managing projects by resolving problems, encourage innovations and improve communication across the SME (Drury, 2018). VA also enables people's contribution to the value-added process by continuously focusing on products design and services. Finally, VA provides risk reduction and continuous improvement of SMEs (Ismail et al., 2010). To achieve the above, VA undertakes activities such as cost analysis of products' functions and evaluates alternatives. Secondly, VA recommends to management issues that may facilitate environmental and social protection in product design for manufacturing SMEs (Ramli et al., 2013). Hence, integration of this innovative MAP into manufacturing SMEs' strategy may assist to strive towards environmental and social sustainability. 


\section{Conclusion}

To address the problem of this research, the systematic literature review discovered that manufacturing SMEs exert considerable pressure on the environment and society through their collective impact of smaller activities (Wangombe, 2013). These impacts could be traced and controlled by using innovative MAPs as a strategic tool which may provide precise information to advance manufacturing SMEs' social and environmental disclosure on its performance to promote their sustainability. The summary of the findings is presented in Fig. 5 to show the identified innovative MAPs, how they may impact manufacturing SMEs strategic policies and operations to promote their sustainability.

From Fig. 5, the research concludes that innovative MAPs will enable manufacturing SMEs to protect the environment and society through integrating sound environmental; health and safety; supply chain management and recycling polices that may enhance their operational efficiency and subsequently promote their achievement of economic sustainability in the long run.

The research has also contributed to:

- Creating internal and external awareness on the complex environment in which manufacturing SMEs' operate, and the need to consult them when enacting policies that may impact the sector.

- Educating manufacturing SMEs on available innovative MAPs that can be integrated into their strategy to achieve environmental and social sustainability in the economy;

- Breaching the existing gap between theory and practice by identifying seven (7) innovative MAPs that manufacturing SMEs can integrate into their strategies to achieve sustainability, and

- Add to the extant literature of management accounting.

The research had the following limitations:

- A limitation of a qualitative research approach to data analyses is that findings cannot be extended to the broader population and its equivalent degree of conviction compared to quantitative. It is because the findings of this research are not tested to ascertain whether they are statistically significant or due to chance.

- The research focused on manufacturing SMEs only and is not open to analyses of the whole SME sector, hence the findings cannot be generalised to cover the whole SMEs sector.

- The research seeks to identify only innovative MAPs that can promote manufacturing SMEs sustainability considering environmental and social impacts in decision-making with regard to economic challenges.

The above limitations notwithstanding, it is believed that this research has resulted in insights for scholars and practitioners. It is hoped that this research will also inspire further research in the discipline of management accounting to identify factors; strategic procedures; and the environmental and social benefits of integrating these identified innovative MAPs into manufacturing SMEs to achieve sustainability. 


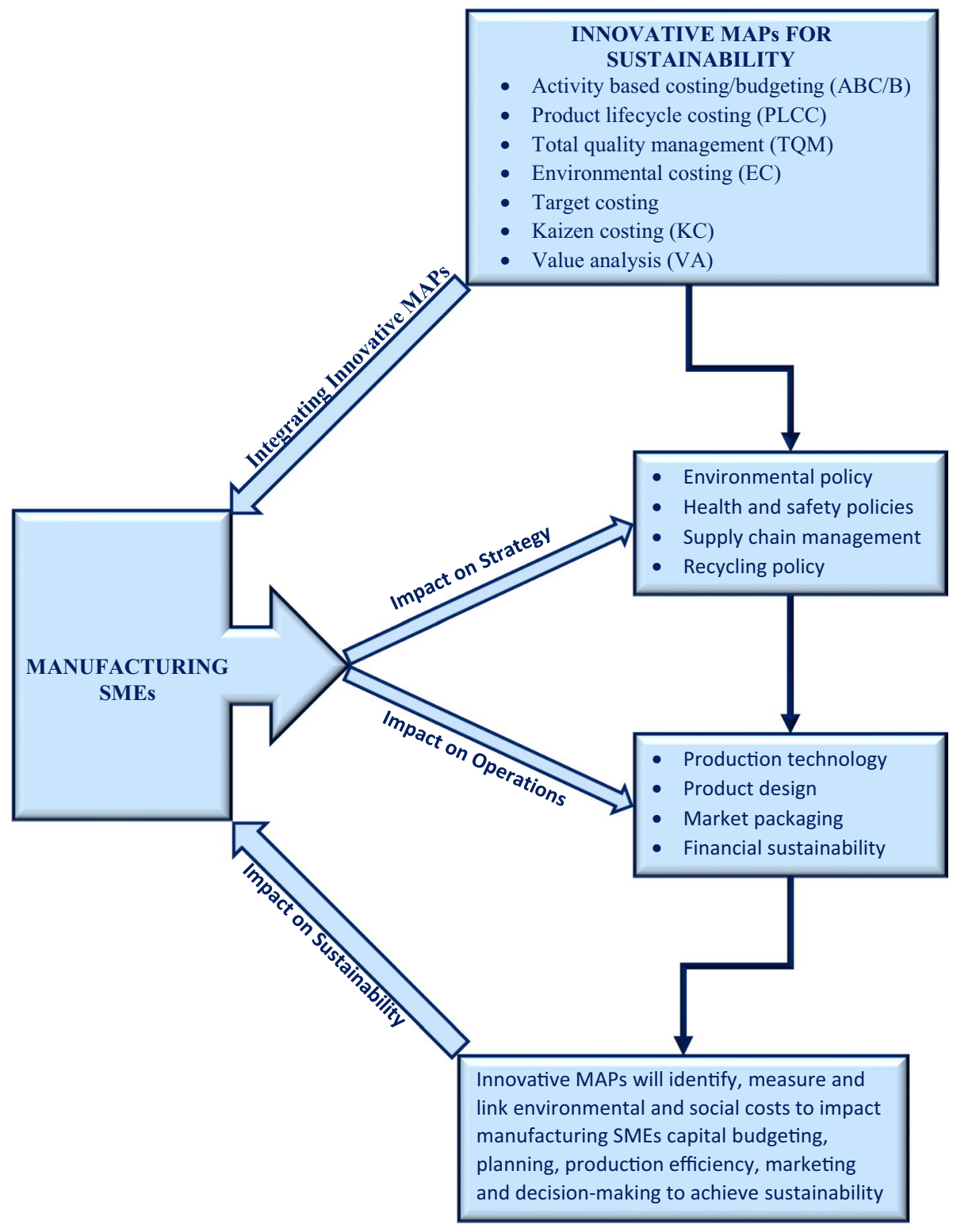

Fig. 5 Innovative MAPs impacting manufacturing SMEs policies and operations for sustainability

\section{Appendix}

See Table 1. 


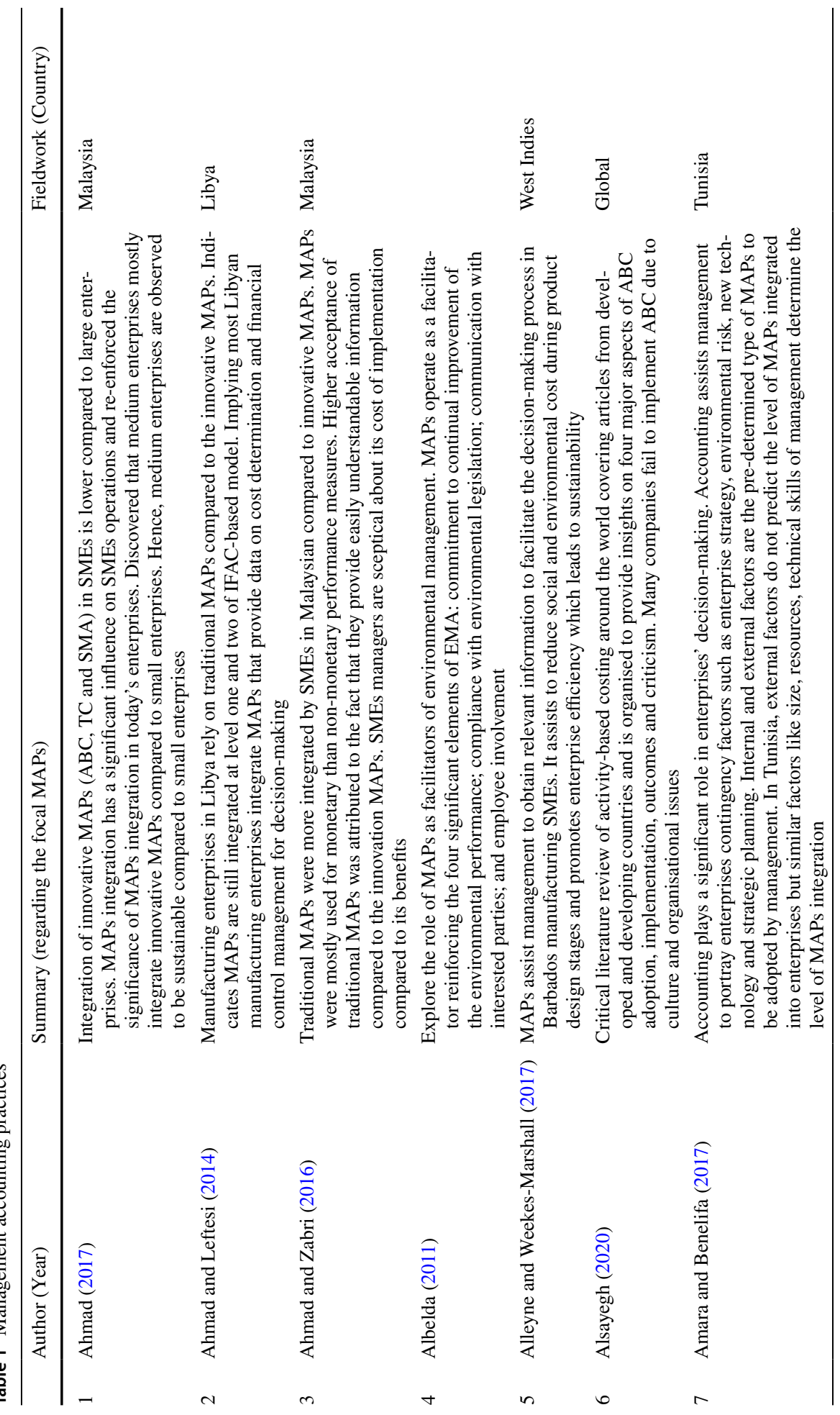




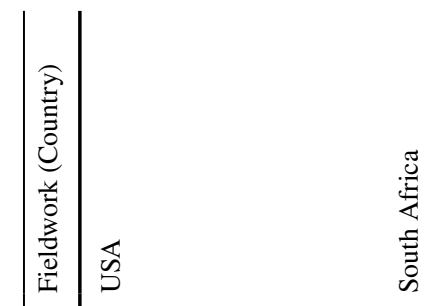

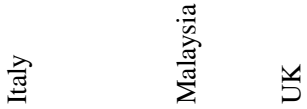

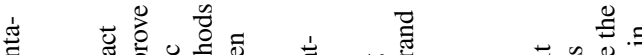

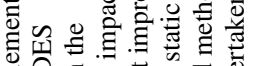

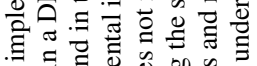

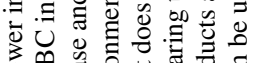

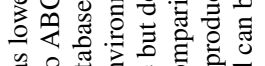

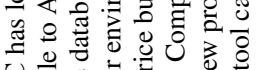

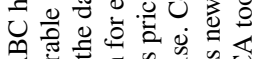

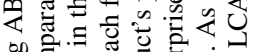

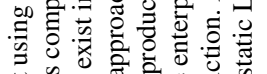

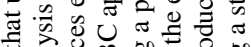

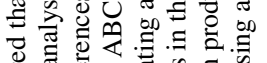

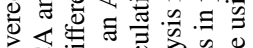

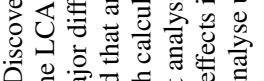

Q

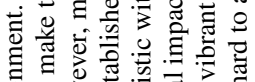

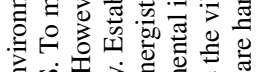

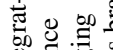

$\Xi$

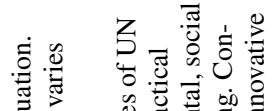

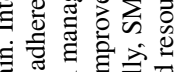

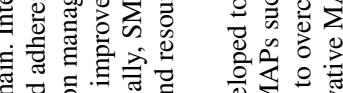

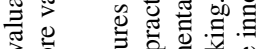

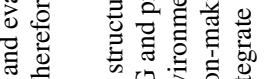

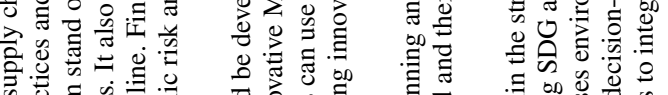

के

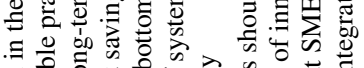

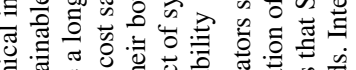

घี

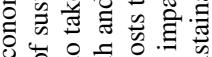

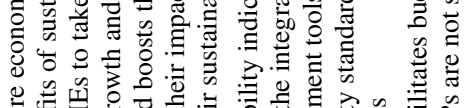

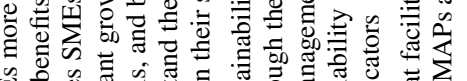

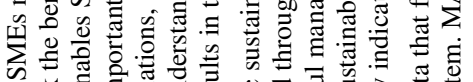

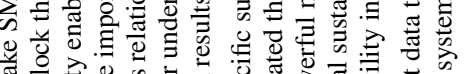

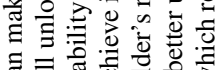

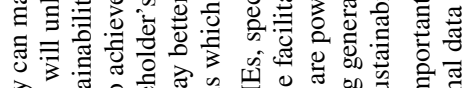

$\because$ of $0 \begin{aligned} & 0 \\ & 0\end{aligned}$

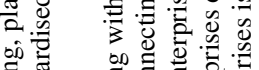

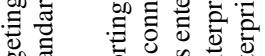

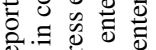

을 $\cong$

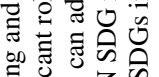

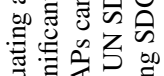

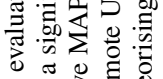

垴

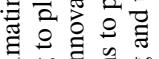
क्ष

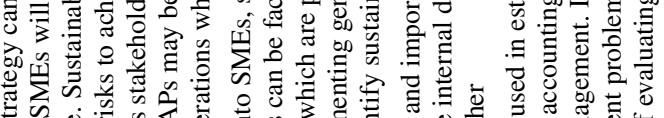

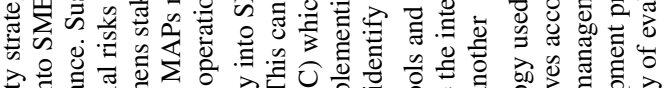

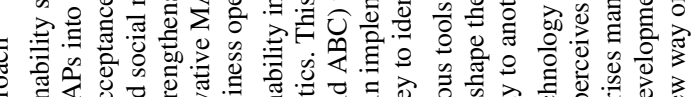

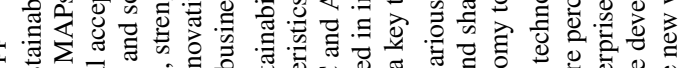

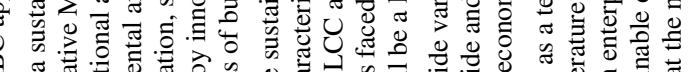

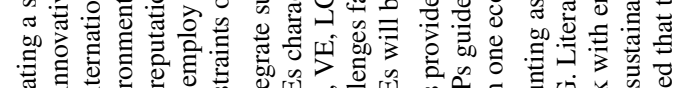

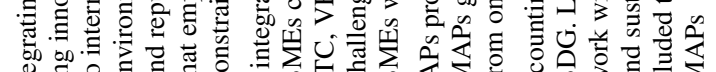

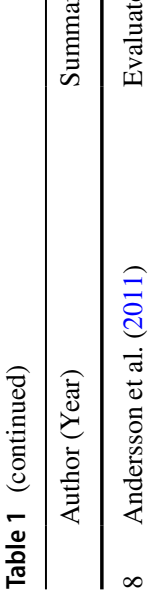

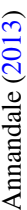

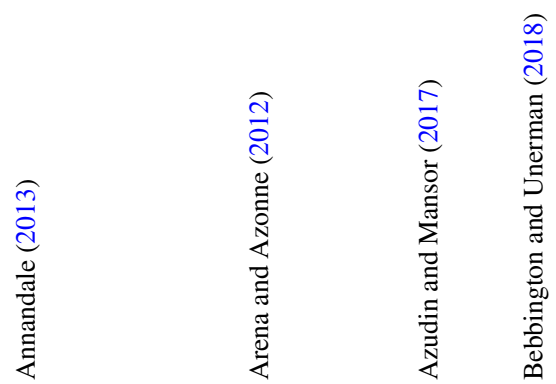

$a$

으 


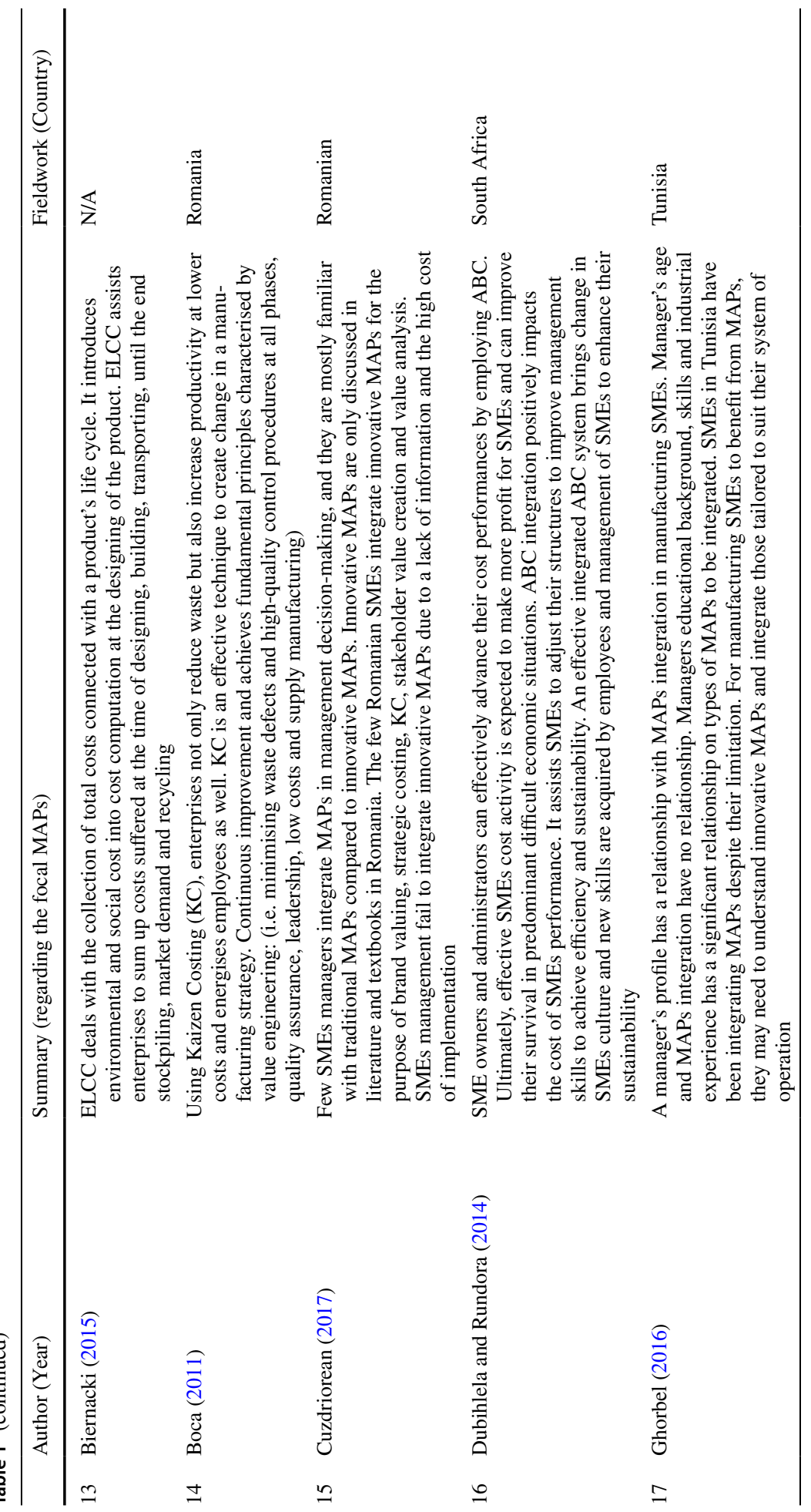




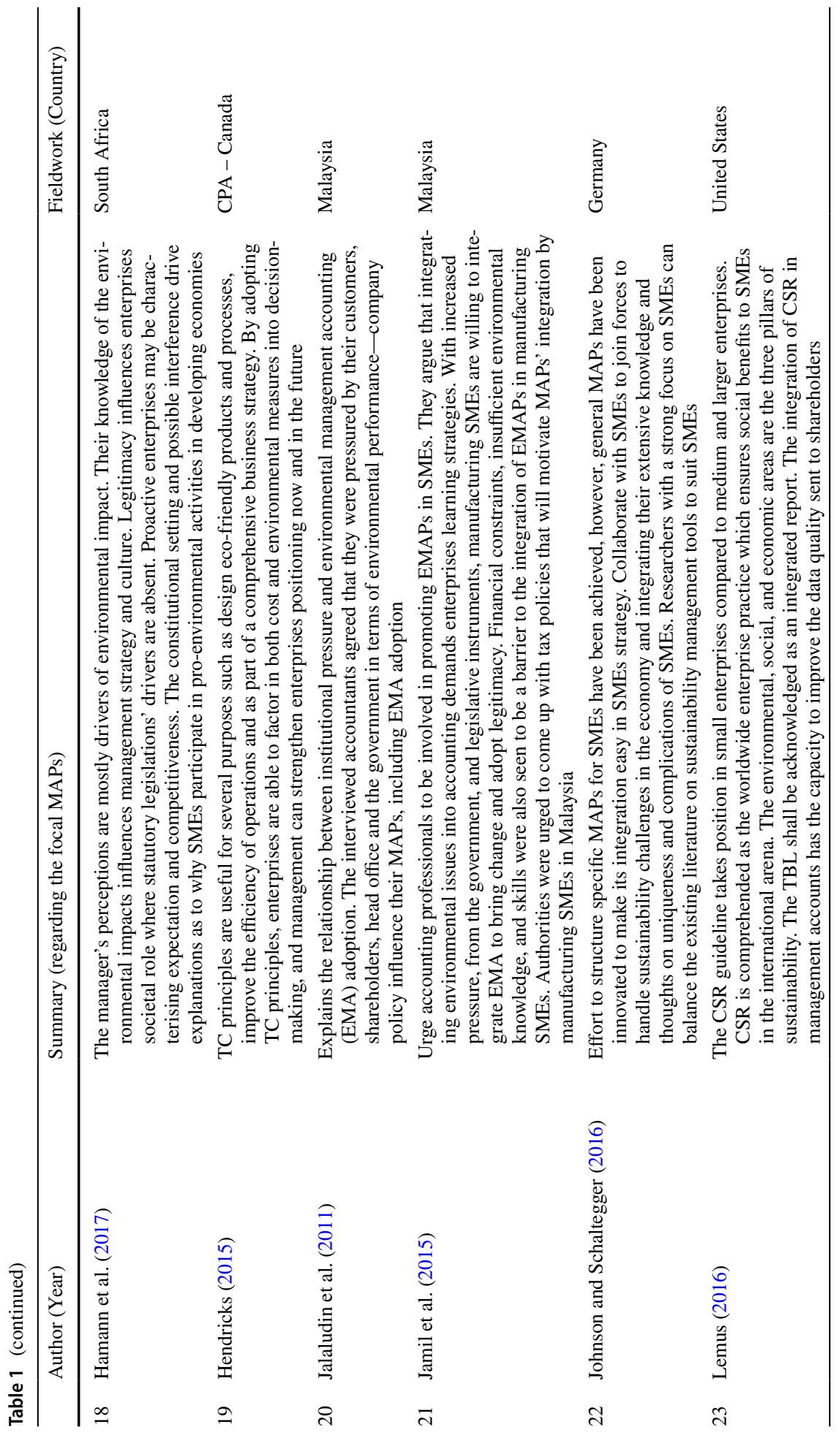




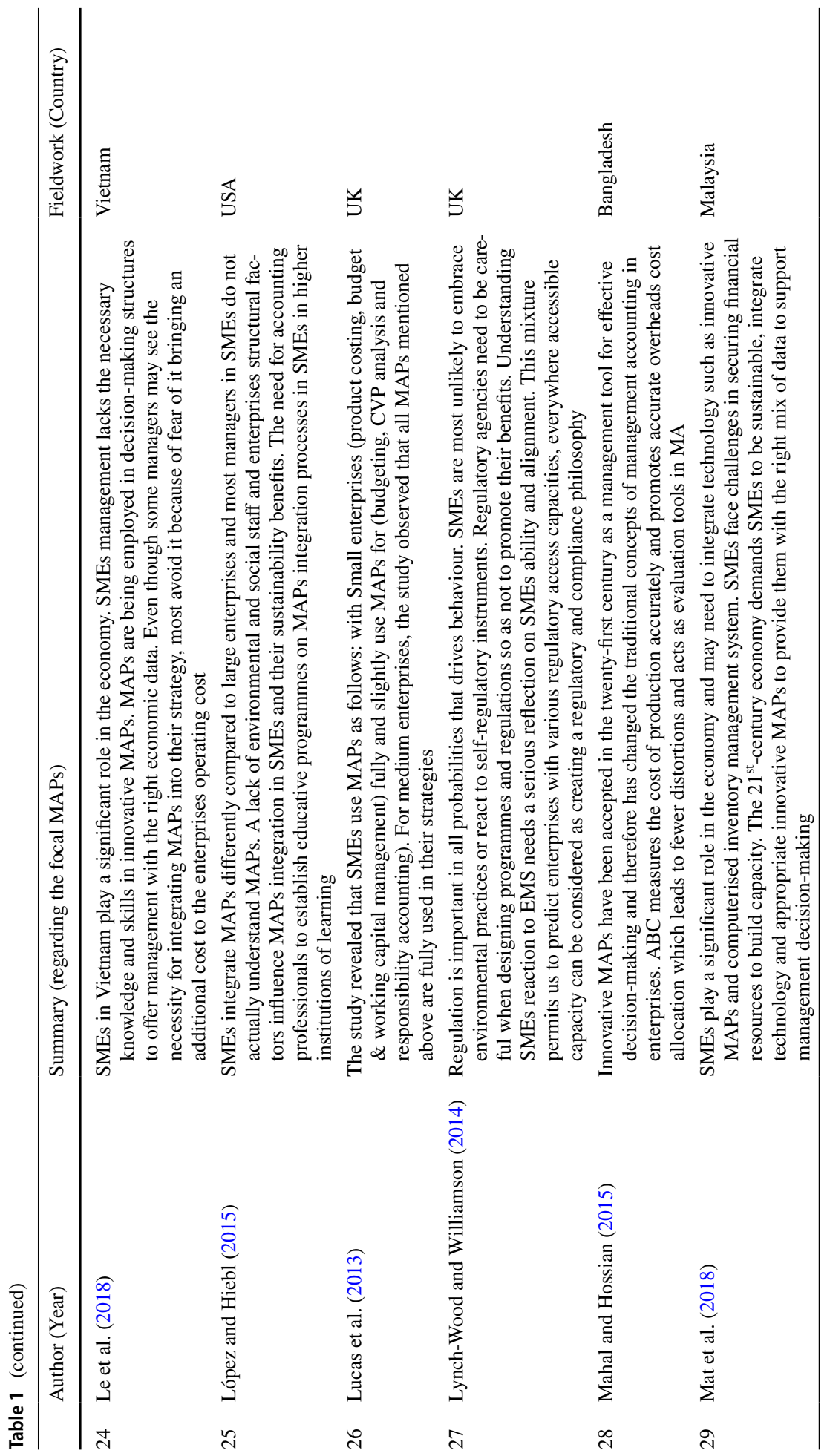




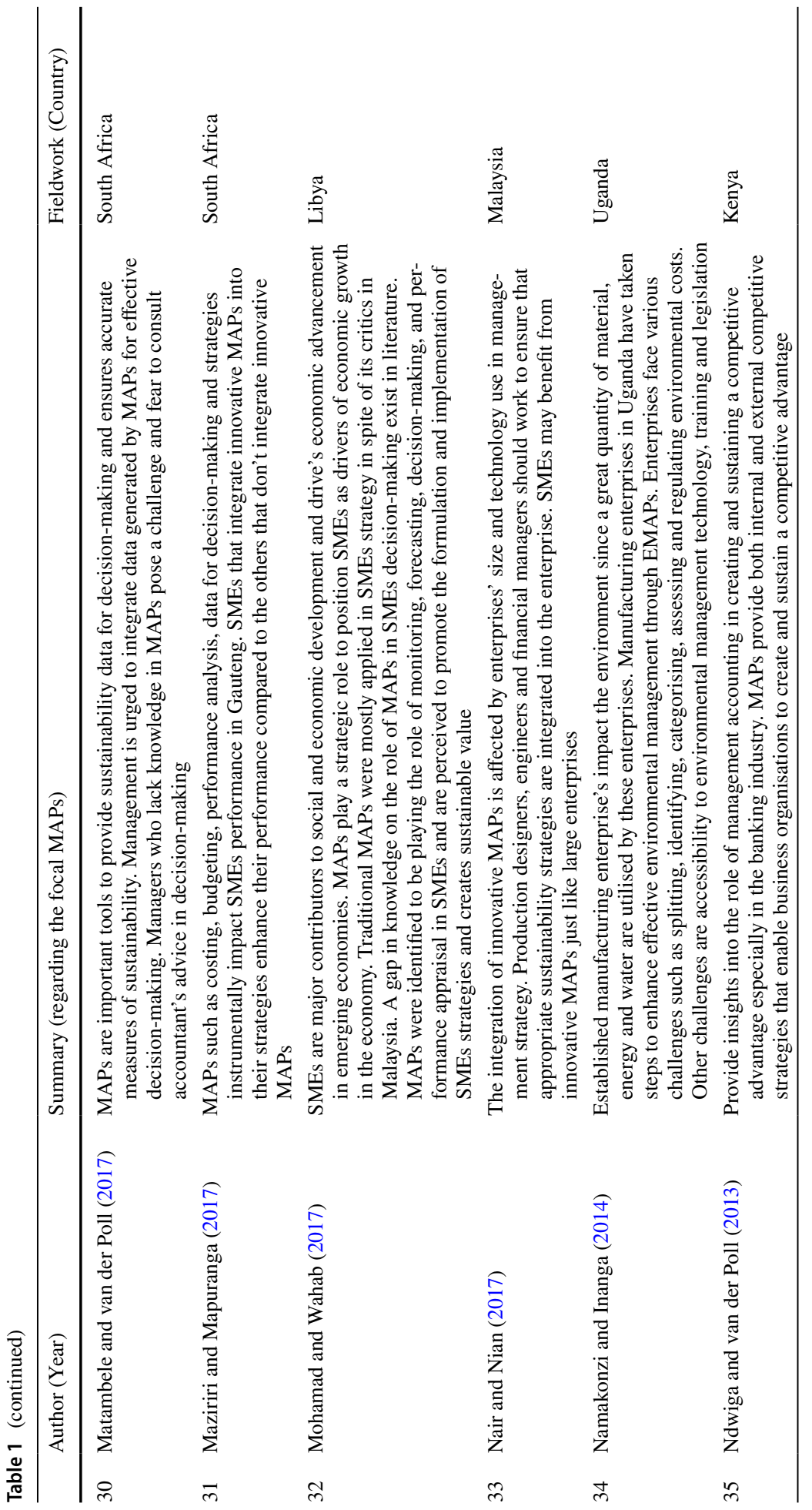




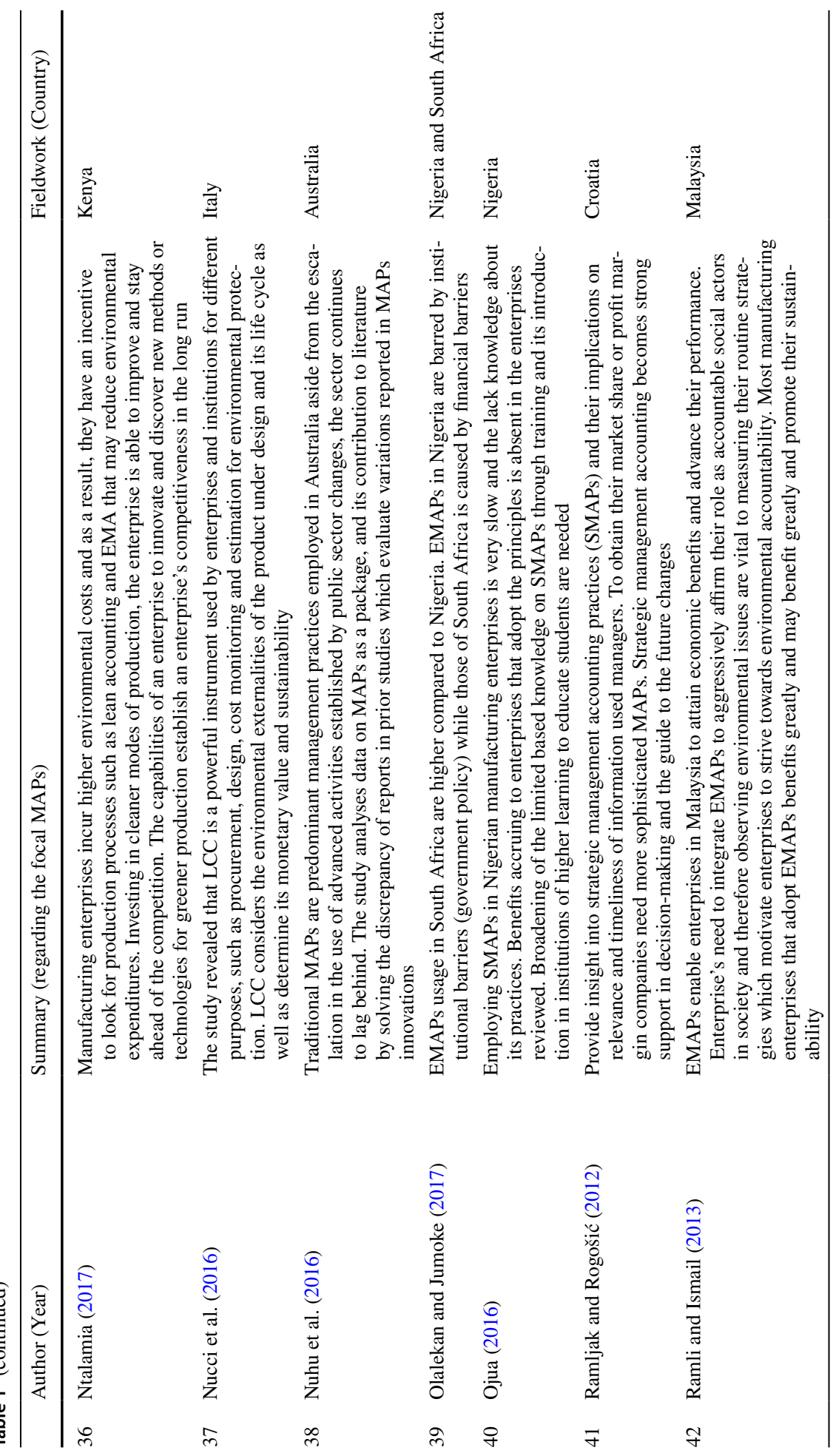




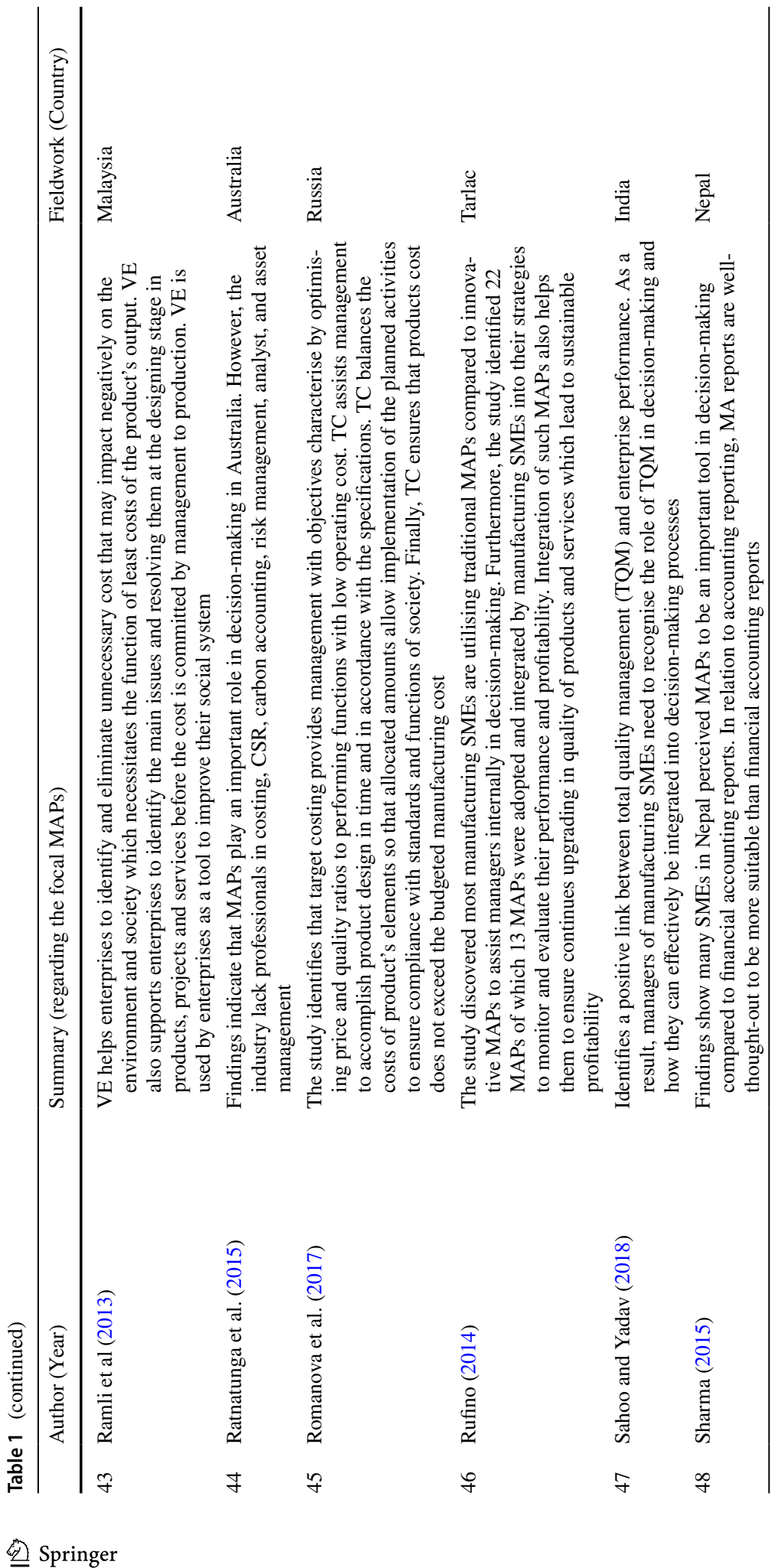




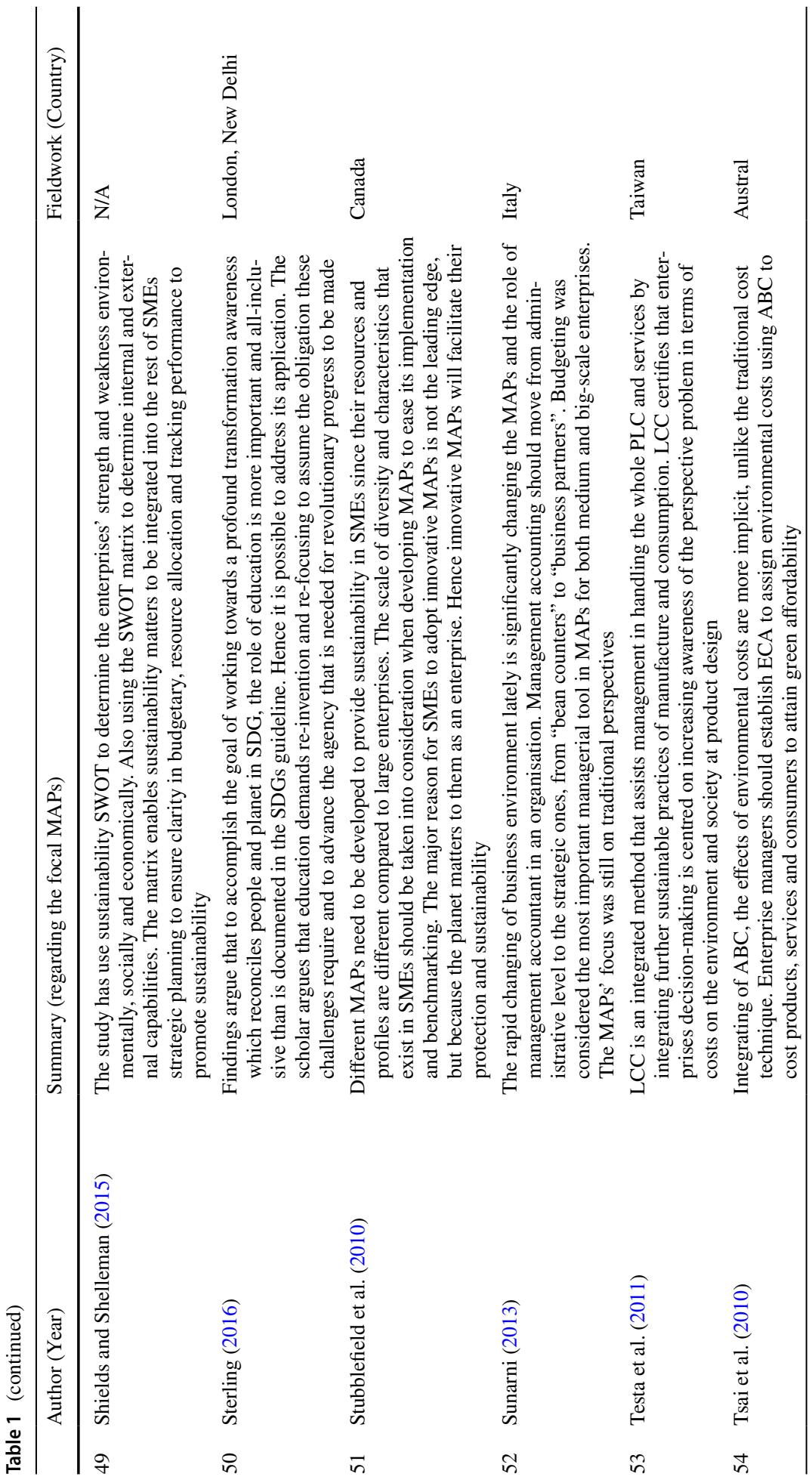




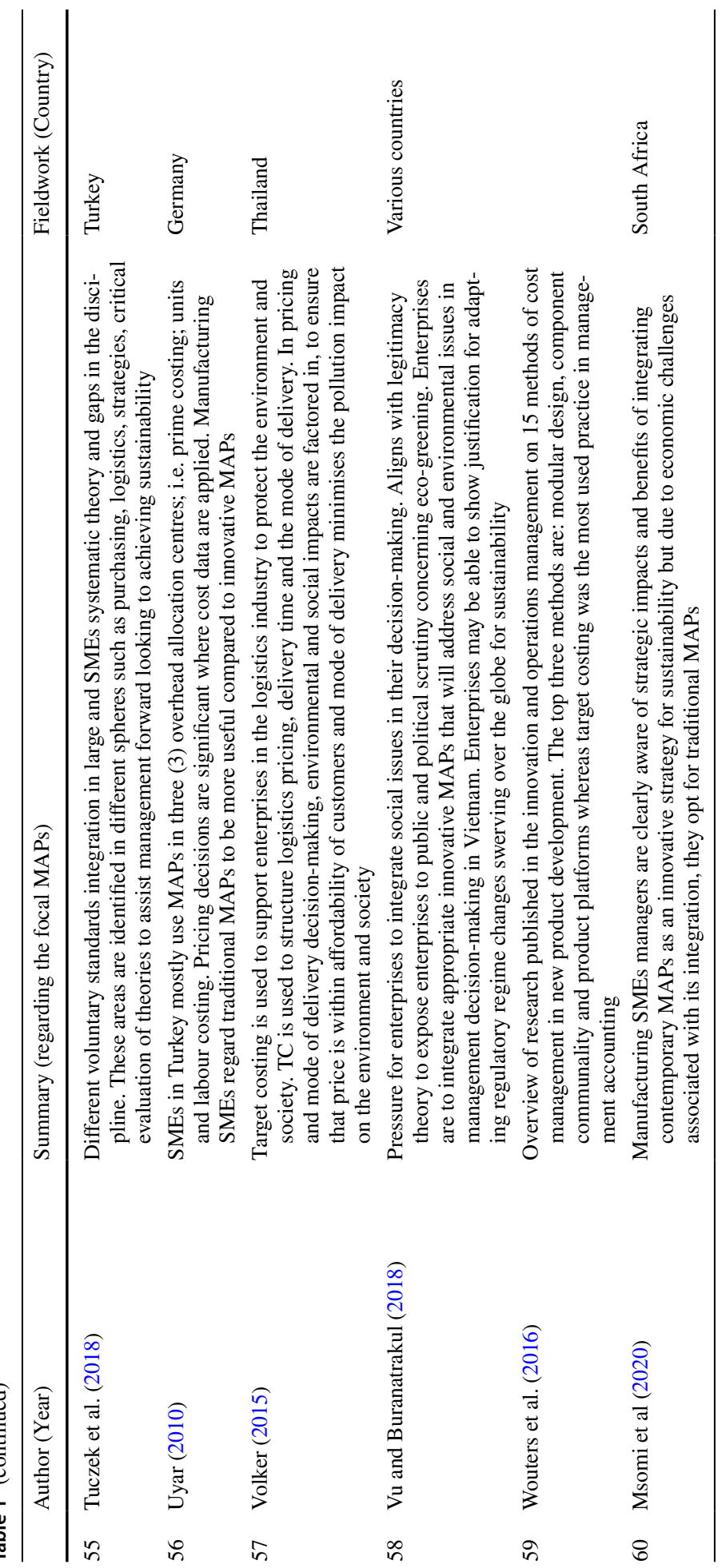


Open Access This article is licensed under a Creative Commons Attribution 4.0 International License, which permits use, sharing, adaptation, distribution and reproduction in any medium or format, as long as you give appropriate credit to the original author(s) and the source, provide a link to the Creative Commons licence, and indicate if changes were made. The images or other third party material in this article are included in the article's Creative Commons licence, unless indicated otherwise in a credit line to the material. If material is not included in the article's Creative Commons licence and your intended use is not permitted by statutory regulation or exceeds the permitted use, you will need to obtain permission directly from the copyright holder. To view a copy of this licence, visit http://creativecommons.org/licenses/by/4.0/.

\section{References}

Ahmad, K. (2017). The implementation of management accounting practices and its relationship with performance in small and medium enterprises. International Review of Management and Marketing, 7(1), 342-353

Ahmad, K. \& Zabri, S.M. (2016). Management Accounting Practices Among Small and Medium Enterprises, In IBIMAC 2016: Proceedings of the $28^{\text {th }}$ International Business Information Management Association Conference, Seville, Spain, pp. 3627-3637.

Ahmad, N.S.M. \& Leftesi, A. (2014). An Exploratory Study of the Level of Sophistication of Management Accounting Practices in Libyan Manufacturing companies. International Journal of Business \& Management, II(2), 1-10. http://www.iises.net/?p=10277

Albelda, E. (2011). The role of management accounting practices as the facilitator of environmental management. Sustainability Accounting, Management and Policy Journal. https://doi.org/10.1108/ 20408021111162137

Alkhajeh, M. H. A., \& Khalid, A. A. (2018). Management accounting practices (MAPs) impact on small and medium enterprise business performance within the gauteng province of South Africa. Journal of Accounting and Auditing: Research \& Practices. https://doi.org/10.5171/2018.345766

Alleyne, P., \& Weekes-Marshall, D. (2011). An exploratory study of management accounting practices in manufacturing companies in Barbados. International Journal of Business and Social Science, 2(9), 49-58

Alsayegh, M. F. (2020). Activity based costing around the world adoption, implementation, outcomes and criticism. Journal of Accounting and Finance in Emerging Economies, 6(1), 251-262. https:// doi.org/10.26710/jafee.v6i1.1074

Amara, T., \& Benelifa, S. (2017). The Impact of external and internal factors on the management accounting practices. International Journal of Finance and Accounting. https://doi.org/10.5923/j. ijfa.20170602.02

Andersson, J., Skoogh, A. \& Johansson, B. (2011). Environmental activity-based costing using discrete event simulations. Proceedings of the 2011 Winter Simulation Conference. In S. Jain, R.R. Creasy, J. Himmelspach, K.P. White, and M. Fu, eds. Pp. 891-902.

Annandale, M. (2013). Can SMEs benefit from sustainability? Accountancy SA. 54-55. https://www. accountancysa.org.za/special-feature-can-smes-benefit-from-sustainability/ Accessed 19 March 2019.

Arena, M., \& Azzone, G. (2012). A process-based operational framework for sustainability reporting in SMEs. Journal of Small Business and Enterprise Development. https://doi.org/10.1108/1462600121 1277460

Ayub, S. (2018). Development of SMEs sector govt's top priority: Governor. The Nation. https://nation. com.pk/28-Nov-2018/development-of-sme-sector-govt-s-top-priority-governor/Accessed 13 February 2019.

Azudin, A., \& Mansor, N. (2017). Management accounting practices of SMEs: The impact of organizational DNA business potential and operational technology. Asia Pacific Management Review, 23(3), 222-226

Barone, A. (2020). What is total quality management (TQM)? Investopedia https://www.investopedia.com/ terms/t/total-quality-management-tqm.asp Accessed 13 February 2020.

Bashir, M., Tanveer, A. M., \& Azeem, M. (2008). Reliability and validity of qualitative and operational research paradigm. Pakistan Journal of Statistics and Operation Research, 4(1), 35. https://doi.org/10. 18187/pjsor.v4i1.59

Bebbington, J., \& Unerman, J. (2018). Achieving the United Nations sustainable development goals: An enabling role for accounting research. Accounting, Auditing and Accountability Journal, 31(1), 2-24. https://doi.org/10.1108/AAAJ-05-2017-2929 
Biernacki, M. (2015). Environmental life cycle costing (ELCC) in the aspect of cost management in the company. Finanse, Rynki Finansowe, Ubezpieczenia. https://doi.org/10.18276/frfu.2015.77-31

Boca, G. D. (2011). Kaizen methodology in quality management to reduce wastes. Seria Stiinte Economice, $21,375-381$

Bonvoisin, J., Stark, R., \& Seliger, G., et al. (2017). Fields of research in sustainable manufacturing. In R. Stark (Ed.), Sustainable manufacturing: Challenges, solutions and implementation perspectives. (pp. 3-20). Springer Nature.

Bryman, A., \& Bell, E. (2015). Business research methods. Oxford University Press.

Capros, P., de Vita, A., Tasios, N., Siskos, P., Kannavou, M., Petropoulos, A., et al. (2016). EU Reference scenario 2016: Energy, transport and GHG emissions trends to 2050. EU Reference scenario, European Commission, Luxembourg. https://ec.europa.eu/energy/sites/ener/files/documents/ref2016_ report_final-web.pdf Accessed 19 February 2019.

CIMA. (2014) Global management accounting principles: Driving better business through improved performance. http://www.cimaglobal.com/Global/2015\%20syllabus/GMAP_executive\%20summary.pdf Accessed 19 February 2019.

Commonwealth of Australia. 2018. Financial Services and Small and Medium-Sized Enterprises (SMEs) https://financialservices.royalcommission.gov.au/publications/Documents/financial-services-andsmall-and-medium-sized-enterprises-paper-12.pdf Accessed 24 February 2021.

Cooper, D. R., \& Schindler, P. S. (2014). Business research methods. (12th ed.). McGraw-Hill/Irwin.

Creswell, J. (2014). Research design: Quantitative, qualitative mixed methods approaches. (4th ed.). Sage.

Cuzdriorean, D.D. (2017). The use of management accounting practices by Romanian Small and MediumSized Enterprises: A field study. Journal of Accounting and Management Information Systems, 16(2), 291-312. https://econpapers.repec.org/scripts/redir.pf?u=http\%3A\%2F\%2Fonline-cig.ase.ro\%2FReP Ec\%2Fami\%2Farticles\%2F16_2_4.pdf;h=repec:ami:journl:v:16:y:2017:i:2:p:291-312

Drury, C. (2018). Management and Cost Accounting. (10th ed.). Cengage Learning.

Dubihlela, J., \& Rundora, R. (2014). Employee training, managerial commitment and implementation of activity based costing: Impact on performance of SMEs. International Journal of Economics and Business Research. https://doi.org/10.19030/iber.v13i1.8354

European Commission. 2015. User Guide to the SME Definition. https://ec.europa.eu/regional_policy/sourc es/conferences/state-aid/sme/smedefinitionguide_en.pdf Accessed 24 February 2021.

Ghorbel, J. (2016). The relationship between the profile of manager and management accounting practices in Tunisian SMIs. International Journal of Academic Research in Accounting, Finance and Management Sciences, . https://doi.org/10.6007/IJARAFMS/v6-i1/1980

Hamann, R., Smith, J., Tashman, P., \& Marshall, R. S. (2017). Why do SMEs go green? An analysis of wine firms in South Africa. Business and Society Journal, 56(1), 23-56. https://doi.org/10.1177/00076 50315575106

Hendricks, J.R. (2015). Managing environmental sustainability using target costing principles. Chartered Professional Accountants Canada. CAM-1, 1-32.

International Organization for Standardization (2016). ISO 14004:2016: Environmental management systems: General guidelines on implementation. https://www.iso.org/standard/60856.html Accessed 12 February 2019. Geneva, ISO.

IoDSA. (2016). King IV: Report on Corporate Governance for South Africa. https://cdn.ymaws.com/www. iodsa.co.za/resource/collection/684B68A7-B768-465C-8214-E3A007F15A5A/IoDSA_King_IV_ Report_-_WebVersion.pdf Accessed 3 January 2017.

Ismail, A., Aminzadeh, R., Aram, A., \& Arshad, I. (2010). Using of value engineering in main road construction. Journal of Applied Sciences. https://doi.org/10.3923/jas.2010.2950.2953

Jalaludin, D., Sulaiman, M., \& Ahmad, N. N. N. (2011). Understanding environmental management accounting (EMA) adoption: A new institutional sociology perspective. Social Responsibility Journal. https://doi.org/10.1108/17471111111175128

Jamil, C. Z. M., Mohamed, R., Muhammad, F., \& Ali, A. (2015). Environmental management accounting practices in small medium manufacturing firms. Procedia-Social and Behavioral Sciences, 172, 619-626

Johnson, M. P., \& Schaltegger, S. (2016). Two decades of sustainability management tools for SMEs: How far have we come? Journal of Small Business Management. https://doi.org/10.1111/jsbm.12154

Kefasi, E.(2019). Management accounting practices and the performance of manufacturing small and medium enterprises in Cape Town. Cape Peninsula university of Technology. http://etd.cput.ac.za/handle/20.500.11838/3031

Le, T. T. O., Bui, T. N., \& Tran, M. D. (2018). Management accounting information in Vietnamese small and medium sized-enterprises. Accounting and Finance Research. https://doi.org/10.5430/afr.v7n1p 130 
Lemus, E. (2016). The importance of CSR in financial reporting standards. Global Journal of Management and Business Research: Accounting and Auditing, 16(2), 24-32

López, O. L., \& Hiebl, M. R. W. (2015). Management accounting in small and medium-sized enterprises: Current knowledge and avenues for further research. Journal of Management Accounting Research, 27(1), 81-119

Lucas, M., Prowle, M. \& Lowth, G. (2013). Management accounting practices of UK small-medium-sized enterprises (SMEs). Improving SME performance through management accounting education. Chartered Institute of Management Accountants UK, 9(4), 1-13. https://www.cimaglobal.com/Documents/ Thought_leadership_docs/Management\%20and\%20financial\%20accounting/ManagementAccounting PracticesOfSmall-Medium-SizedEnterprises.pdf Accessed 14 February 2019.

Lynch-Wood, G., \& Williamson, D. (2014). Understanding SMEs responses to environmental regulation. Journal of Environmental Planning and Management. https://doi.org/10.1080/09640568.2013.793174

Mahal, I., \& Hossain, M. A. (2015). Activity based costing (ABC)—An effective tool for better management. Research Journal of Finance and Accounting., 6(4), 66-74

Mahembe, E., Chiumya, C. \& Mbewe, P. (2011). Literature Review on Small and Medium Enterprises' Access to Credit and Support in South Africa. Prepared for: National Credit Regulator, Underhill Corporate Solutions. https://www.smallbusinessinstitute.co.za/wp-content/uploads/2019/12/NCRLi terature-Review-on-SME-Access-to-Credit-in-South-Africa_Final-Report_NCR_Dec-2011.pdf Accessed12 February 2019.

Marshall, C., \& Rossman, G. B. (2014). Designing qualitative research. (6th ed.). Sage.

Mat, T. Z. T., Johari, N. R. M., Azis, M. A. A., \& Hashim, M. R. (2018). Influence of information technology, skills and knowledge, and financial resources on inventory management practices amongst small and medium retailers in Malaysia. Asia-Pacific Management Accounting Journal, 13(2), 173-200

Matambele, K. \& van der Poll, H.M. (2017). Management Accounting Tools for Sustainability Information Decision-making and Financial Performance. Alternation, 20, 189-213. https://journals.ukzn.ac. za/index.php/soa/article/view/822

Matsoso, M. L., \& Benedict, O. H. (2014). Non-financial performance measures in small medium enterprises' supply chain management. Journal of Economics. https://doi.org/10.1080/09765239.2014. 11885001

Maziriri, E. T., \& Mapuranga, M. (2017). The impact of management accounting practices (MAPs) on the business performance of small and medium enterprises within the gauteng province of South Africa. Journal of Accounting and Management, 7(2), 12-25

Mind Tools. (2018). Kaizen, gaining the full benefits of continuous improvement. https://www.mindtools. com/pages/article/newSTR_97.htm Accessed 18 August 2018.

Mohamad, Z., \& Wahab, K. A. (2017). The relationship between management accounting practices and performance of the small and medium enterprises in Libya: A proposed conceptual framework. European Journal of Business and Management, 9(26), 108-115

Msomi, M. P., Ngibe, M., \& Bingwa, L. L. (2020). The Integration of management accounting practices as an innovative strategy towards sustaining small businesses operating in Ethekwini metropolitan, South Africa. Problems and Perspective in Management, 18(3), 268-281. https://doi.org/10.21511/ppm. 18(3).2020.23

Nair, S., \& Nian, Y. S. (2017). Factors affecting management accounting practices (MAPs) in Malaysia. International Journal of Business and Management. https://doi.org/10.5539/ijbm.v12n10p177

Namakonzi, R. \& Inanga, I. (2014). Environmental management accounting and environmental management in manufacturing industries in Uganda. Working Paper No. 2014/39 Maastricht School of Management. https://econpapers.repec.org/scripts/redir.pf?u=http\%3A\%2F\%2Fweb2.msm.nl\%2FRePEc\% 2Fmsm\%2Fwpaper\%2FMSM-WP2014-39.pdf;h=repec:msm:wpaper:2014/39

Namazi, M. (2013). Role of the agency theory in implementing management's control. Journal of Accounting and Taxation. https://doi.org/10.5897/JAT11.032

Ndwiga, N. M., \& van der Poll, H. M. (2013). The role of management accounting in creating and sustaining competitive advantage: A case study of equity bank Kenya. Alternation, 8, 122-142

Neziraj, E. Q., \& Shaqiri, A. B. (2018). The impact of information technology in decision-making process of companies in Kosovo. Informatol, 51(1-2), 13-23

Ntalamia, W.L. (2017). Factors influencing adoption of environmental management accounting (EMA) practices among manufacturing firms in Nairobi, Kenya. Journal of Finance, 5(2), 1-16. http://hdl. handle.net/123456789/3420

Nucci, B., Iraldo, F., \& de Giacomo, M. R. (2016). The relevance of life cycle costing in green public procurement. Economics and Policy of Energy and the Environment. https://doi.org/10.3280/EFE20 16-001005 
Nuhu, N. A., Baird, K., \& Appuhami, R. (2016). The Association between the use of management accounting practices with organizational change and organizational performance. In M. J. Epstein \& M. A. Malina (Eds.), Advances in management accounting. (pp. 67-98). Emerald Publishing Limited.

Ojua, M. O. (2016). Strategic management accounting practices among indigenous Nigerian manufacturing enterprises. Open Science Journal, 1(2), 1-14. https://doi.org/10.23954/osj.v1i2.395

Olalekan, I. O., \& Jumoke, O. O. (2017). Identifying barriers to environmental management accounting practices: A comparative study of Nigeria and South Africa. The Business and Management Review, 9(1), 168-179

Prowle, M., \& Lucas, M. (2016). Management accounting in the contemporary business world. Red Globe Press.

Radović-Marković, M. \& Vučeković, M. (2015). The role of information management in decision making and business success. In: Challenges to promoting entrepreneurship, leadership and competitiveness / International conference employment, education and enterpreneurship. Faculty of business economics and entrepreneurship; Belgrade; Chicago, pp. 175-187. ISBN 978-86-6069-116-5 (FBEE); 978-1-4951-7656-2(BCG).

Ramli, A., \& Ismail, M. S. (2013). Environmental management accounting practices: A survey of ISO14001 certified Malaysian organisations. Journal of Energy and Policy, 3(11), 415-432

Ramli, A., Sulaiman, S., \& Mitchell, F. (2013). Challenges in management accounting innovation adoption: Evidence from Malaysian companies. International Journal of Finance and Accounting. https://doi.org/10.5923/j.ijfa.20130202.13

Ramljak, B., \& Rogošić, A. (2012). Strategic management accounting practices in Croatia. The Journal of International Management Studies, 7(2), 93-100

Ratnatunga, J., Tse, M. S. C., \& Wahyuni, D. (2015). Societal role expectations of management accounting professionals: An Australian study. Advances in Management Accounting. https://doi.org/10. 1108/S1474-787120150000025002

Rebitzer, G., \& Hunkeler, D. (2003). Life cycle costing in LCM: Ambitions, opportunities, and limitations. International Journal of Life Cycle Assessment. https://doi.org/10.1007/BF02978913

Romanova, S. V., Popova, T. D., Slatviskaya, I. I., \& Mironova, D. D. (2017). Application of target costing in social infrastructure construction projects. Revista Espacios, 38(33), 37-47

Rufino, H. D. (2014). The management accounting practices (MAPs) of small and medium-sized manufacturing enterprises in the city of Tarlac. Review of Integrative Business and Economics Research, 4(1), 55-74

Sahoo, S. \& Yadav, S. (2018). Total quality management in Indian manufacturing SMEs. $15^{\text {th }}$ Global Conference on Sustainable manufacturing. Procedia Manufacturing 21(2018); 541-548. https:// doi.org/10.1016/j.promfg.2018.02.155

Saunders, M., Lewis, P., \& Thornhill, A. (2016). Research methods for business students. (7th ed.). Pearson Education Limited.

SBA. 2013 Size Standards. https://www.sba.gov/federal-contracting/contracting-guide/size-standards\# section-header-0 Accessed 22 February 2021.

Shah, H., Malik, A., \& Malik, M. S. (2011). Strategic management accounting-A messiah for management accounting? Australian Journal of Business and Management Research, 1(4), 1-7

Sharma, G. (2015). Practices of financial and management accounting: Evidence from small and medium-sized enterprises of Nepal. Journal of Nepalese Business Studies. https://doi.org/10.3126/ jnbs.v9i1.14597

Shields, J. \& Shelleman, J.M. (2015). Integrating sustainability into SMEs strategy. Journal of Small Business Strategy, 25(2), 59-78. Retrieved from https://libjournals.mtsu.edu/index.php/jsbs/article/ view/561

Smith, S. S. (2015). Accounting, governance and stakeholder reporting and economic value creation. Journal of Applied Business and Economics, 17(2), 76-80

South Africa. National Small Enterprise Act (2019) Act No 399 of 2019 Government Gazette, 110 (42304). https://www.gov.za/sites/default/files/gcis_document/201903/423041gon399.pdf

Sterling, S. (2016). A Commentary of Education and Sustainable Development Goals. Journal of Education for Sustainable Development, 10.1177\%2F0973408216661886

Stubblefield, L. E., Martens, M. L., \& Cho, C. H. (2010). Engaging small- and medium-sized businesses in sustainability. Sustainability Accounting, Management and Policy Journal. https://doi.org/10. 1108/20408021011089239

Sunarni, C.W. (2013). Management accounting practices and the role of management accountant: Evidence from manufacturing companies throughout Yogyakarta, Indonesia. Review of Integrative Business \& Economics Research, 2(2), 616-626. http://e-journal.uajy.ac.id/id/eprint/18131 
Syakir, M. I., Farhana, A. I. N., Hassan, M. S., Shaharudin, M. S., Hafiidz, J. M., \& Amran, A. (2017). The role of multinational companies for the world sustainable development agenda. Journal of Sustainability Science and Management, 12(2), 228-252

Testa, F., Iraldo, F., Frey, M., \& O’Connor, R. (2011). Life cycle costing, a view of potential applications: From cost management tool to eco-efficiency measurement. In P. Li (Ed.), Supply Chain Management.IntechOpen. https://doi.org/10.5772/15332

Tilt, C. A. (2018). Making social and environmental accounting research relevant in developing countries: A matter of context? Social and Environmental Accountability Journal. https://doi.org/10.1080/09691 60X.2018.1489296

Tsai, W.-H., Lin, T. W., \& Chou, W.-C. (2010). Integrating activity-based costing and environmental cost accounting systems: A case study. International Journal of Business and Systems Research, 4(2), 186-208

Tuanmat, T. Z., \& Smith, M. (2011). Changes in management accounting practices in Malaysia. Asian Review of Accounting, 19(3), 221-242

Tuczek, F., Castka, P., \& Wakolbinger, T. (2018). A review of management theories in the context of quality, environmental and social responsibility voluntary standards. Journal of Cleaner Production. https:// doi.org/10.1016/j.jclepro.2017.12.161

Uyar, A. (2010). Cost and management accounting practices: A survey of manufacturing companies. Eurasian Journal of Business and Economics, 3(6), 113-125. https://www.ejbe.org/index.php/EJBE/article/ view/43

Vandayar, V. (2015). Culture of governance in SMEs essential for the economy. Accountancy SA: Special Feature Influence, pp.54-55. Retrieved from: https://www.accountancysa.org.za/influence-specialfeature-sme-state-of-play-2015/\#culture on 14th April 2016.

Volker, F. (2015). Can target costing be applied in green logistics?-evidence from a conjoint analysis. ECIS, 2015(47), 1-15. https://doi.org/10.18151/7217315

Vu, K. A., \& Buranatrakul, T. (2018). Corporate social responsibility disclosure in Vietnam: A longitudinal study. DLSU Business and Economics Review, 27(2), 147-165

Wangombe, D.K. (2013). Multi-theoretical perspective of corporate environmental reporting: A literature review. Review of Integrated Business and Economic Research, 2(2), 655-671. http://hdl.handle.net/ $11071 / 3773$

Wouters, M., Morales, S., Grollmuss, S., \& Scheer, M. (2016). Methods for cost management during product development: A review and comparison of different kinds of literature. Advances in Management Accounting. https://doi.org/10.1108/S1474-787120150000026005

Publisher's Note Springer Nature remains neutral with regard to jurisdictional claims in published maps and institutional affiliations. 